\title{
MEISTER ECKHART'S TREATISE ON BEING, WHAT IS, AND NOTHING, AND THE RELATIONSHIP BETWEEN HIS COMMENTARIES ON GENESIS (EXPOSITIO ON GENESIS AND BOOK OF THE PARABLES OF GENESIS)
}

\author{
Andrés Quero Sánchez \\ Meister-Eckhart Research Center at the Max-Weber-Kolleg for Advanced Studies, \\ University of Erfurt, Germany
}

\begin{abstract}
This article shows firs that the text hitherto known as the Prologue to the Works of Propositions by Meister Eckhart is in fact his treatise On Being, What is, and Nothing, to which he himself refers in his Sermons and Lectures on the Twenty-fourth Chapter of «Ecclesiasticus». The article also analyses the relationship between the two extant commentaries on Genesis by Eckhart: the Expositio on Genesis and the Book of the Parables of Genesis.
\end{abstract}

Key words: Meister Eckhart, Three-Part Work (Opus tripartitum).

\section{RESUMEN}

El artículo muestra, en primer lugar, cómo lo que hasta ahora se ha venido conociendo como Prólogo a la Obra de las Proposiciones del Maestro Eckhart en realidad ha de ser considerado como su tratado Sobre el Ser el Ente y la Nada, al que él mismo se refiere en sus Sermones y Lecciones sobre el Eclesiástico. En segundo lugar, el artículo analiza la relación entre los dos Comentarios al Génesis del Maestro Eckhart existentes: Su Exposición del Génesis y su Libro de las Parábolas del Génesis.

Palabras clave: Maestro Eckhart, Obra tripartita (Opus tripartitum).

\section{INTRODUCTION: MEISTER ECKHART'S WORKS}

As it is well-known, Meister Eckhart (d. 1328) wrote his works both in Latin and in German, and to be more precise: in Middle High German (Mittelhochdeutsch). With regard to the German works, ${ }^{1}$ we know of three treatises, although the authenticity of one of them (namely the treatise On Detachment) is still questioned among scholars. ${ }^{2}$ The authenticity of the other two extant treatises, that is, The Talks (or Discourses) on Instruction and The Book

1 See Steer, G., «Die Schriften Meister Eckharts in den Handschriften des Mittelalters», in H.-J. Schiewer and K. Stackmann (eds.), Die Präsenz des Mittelalters in seinen Handschriften. Ergebnisse der Berliner Tagung in der Staatsbibliothek zu Berlin - Preußischer Kulturbesitz, 6.-8. April 2000, Tübingen, Niemeyer, 2002, pp. 209-302; Gottschalk, D., «Eckhart's German Works», in J. M. Hackett (ed.), A Companion to Meister Eckhart, Leiden/Boston, Brill, 2013, pp. 137-183.

2 For a summarized discussion on this see Quero-Sánchez, A., «Sein als Absolutheit (esse als abegescheidenheit)», in Id. and G. Steer (eds.), Meister Eckharts Straßburger Jahrzehnt, Stuttgart, Kohlhammer, 2008 (Meister-Eckhart-Jahrbuch 2), pp. 189-218, here pp. 215f., note 92. 
of the Divine Consolation, has never been questioned. ${ }^{3}$ We know, in addition, of more than a hundred German sermons, although some texts which have been edited as sermons should rather be seen as academic, disputed questions (for example German Sermon 105) ${ }^{4}$ or as «Discourses» (or «Speeches») that is, Reden (Middle High German rede) (for example Sermon 52 On Poverty). ${ }^{5}$ There is also a German Poem, the Granum sinapis (Mustard Seed) as well as some prayers, which some scholars think might be works written by Eckhart. ${ }^{6}$ In addition to this, Markus Vinzent, from King's College London, has recently analysed some extant Middle German translations of Eckhart's Latin Bible-Commentaries, contained in two different but related manuscripts, ${ }^{7}$ and shown that they were probably made by Eckhart himself. ${ }^{8}$

In this article, however, I am not going to be concerned with the German but only with the Latin writings of Eckhart, ${ }^{9}$ and only with those Latin writings belonging to what scholars, following a title used by Eckhart himself, ${ }^{10}$ call the Opus tripartitum, that is, the Three-Part Work. The first edition of this work was done by Heinrich Denifle in 1886, who took into consideration only a manuscript he had himself found just a couple of years before in Erfurt:

3 Although Josef Quint edited the Talks on Instruction as Eckhart's Second Treatise, they rather represent an anthology of Eckhart's collationes («Speeches» or «Discourses») published by some anomymous editor, most probably after Eckhart's death; cf. Quero Sánchez, A., «Meister Eckart's Rede von der armuot in the Netherlands: Ruusbroec's Critique and Geert Grote's Sermon on Poverty», in A. -M. Vannier (ed.), Mystique rhénane et Devotion moderne, Paris, Beauchesne, 2017 (in press).

4 See Löser, Fr., «Werkkonzepte und Individualisierung bei Eckhart, Tauler und Seuse», in Id. and D. Mieth (eds.), Religiöse Individualisierung in der Mystik: Eckhart - Tauler - Seuse, Stuttgart, Kohlhammer, 2014 (Meister-Eckhart-Jahrbuch 8), pp. 145-180, here p. 157.

5 Eckhart himself calls this (presumed) sermon a «Dircourse» or «Speech». Cf. German Sermon 52, ed. by G. Steer, in Id. and L. Sturlese (eds.), Lectura Eckhardi. Predigten Meister Eckharts von Fachgelehrten gelesen und gedeutet, Vol. I, Berlin/Cologne/Stuttgart, Kohlhammer, 1998, pp. 168-180, hier p. 180,7-10: Der diz niht enverstât, der enbekümber sîn herze niht dâ mite. Wan alsô lange der mensche niht glîch enist dirre wârheit, sô lange ensol er dise rede niht verstân; wan diz ist ein unbedachtiu wârheit, diu komen ist ûz dem herzen gotes sunder mittel (cf. Die Deutschen Werke [= DW], Vol. II, ed. by J. Quint, Stuttgart, Kohlhammer, 1968-1971 [repr. 1988], p. 506,1-3). Scholars often wonder why no sentence of this in a sense very radical sermon -which I am proposing here to call not a «Sermon» but a «Discourse (or Speech) on Poverty»- was condemned by Pope John XXII nor included in any of the lists with Eckhart's problematic propositions examined during his heresy trial in Cologne. I think the answer is the following: since On Poverty was not a sermon, it had at this time (1306) not yet been published, but it merely circulated as a «Speech» or «Discourse» being only available for some of Eckhart's nearest disciples. Cf. Quero Sánchez, A., «Meister Eckhart's Rede von der armuot» (2017).

6 For a summarized discussion on this see Quero-Sánchez, A., Sein als Freiheit. Die idealistiche Metaphysik Meister Eckharts und Johann Gottlieb Fichtes, Munich/Freiburg i.Br., Alber, 2014, pp. 50f. (note 41) (on the authenticity of the poem Mustard Seed); id., Über das Dasein. Albertus Magnus und die Metaphysik des Idealismus, Stuttgart, Kohlhammer, 2013 (Meister-Eckhart-Jahrbuch. Beiheft 3), p. 131, note 348 (on the authenticity of some extant prayers).

7 These manuscripts are the following: (1) Berlin State Library - Prussian Cultural Heritage, Ms. germ. fol. 986; (2) Library of the Wartburg-Foundation (in the Wartburg, near Eisenach) Ms. 1361-50 (olim Gießen, private ownership [known to Franz Pfeiffer in 1857 before being lost, now rediscovered by Markus Vinzent and Balázs J. Nemes]).

8 See Vinzent, M., «Eckharts deutsche Übersetzung seiner lateinischen Bibelkommentare» in Fr. Löser and R. Schiewer (eds.), Von Schwester Katrei bis zum Frankfurter: Meister Eckharts Wirkung im 14. und 15. Jahrhundert, Stuttgart, Kohlhammer, 2016 (Meister-Eckhart-Jahrbuch 9) (in press).

9 See Beccarisi, A., «Eckhart's Latin Works», in J. M. Hackett (ed.), A Companion to Meister Eckhart (2013), pp. 85-123.

10 Cf. Meister Eckhart, Prologus generalis in Opus tripartitum, n. 2, in Die Lateinischen Werke (= LW), Vol. I/1, ed. by K. Weiß, Stuttgart, Kohlhammer, 1937-1964 (repr. 1988), p. 148,5 (Recensio CT); LW, Vol. I/2, ed. by L. Sturlese, Stuttgart, Kohlhammer, 1987-2011, p. 21,5 (Recensio L): Auctoris intentio in hoc opere tripartito [...]. 
Codex Amplonianus F 181, from the beginning of the $14^{\text {th }}$ century. ${ }^{11}$ Till today, we know of five manuscripts containing Eckhart's Opus tripartitum, indeed, as we will see, four different versions of it:12

1. Erfurt/Gotha, University and Research Library (Universitäts- und Forschungsbibliothek), Department Erfurt, Codex Amplonianus F 181 (dating from the beginning of the $14^{\text {th }}$ century) (Sigle E)

2. Oxford, Bodleian Library, laud[ian] misc[ellanea] 222 (dating from the first half of the $14^{\text {th }}$ century) (Sigle L)

3. Trier, City Library (Stadtbibliothek), $72 / 1056$ (dating from the second half of the $14^{\text {th }}$ century) (Sigle T)

4. Bernkastel-Kues, Library of the St. Nicholas' Hospital (Cusanus Foundation) (Bibliothek des St. Nikolaus-Hospitals), Hs. 21 (written in 1444) (Sigle C)

5. Berlin, State Library - Prussian Cultural Heritage (Preußischer Kulturbesitz), lat. qu. 724 (dating from the first half of the $15^{\text {th }}$ century) (Sigle B)

The last mentioned manuscript (B) only contains Eckhart's Commentary on John's Gospel and so it will not play any role in my following discussion. There are in addition also a Basle manuscript containing numerous excerpts of Eckhart's Opus tripartitum (Sigle K), ${ }^{13}$ but it is not relevant for the question I am concerned with in this paper. In the same way, I will not take into consideration the other twelve extant manuscripts containing some minor Latin works by Eckhart, ${ }^{14}$ since none of them has anything to do with the Three-Part Work. I will just concentrate my efforts on the elucidation of the from number (1) to (4) aforementioned manuscripts, in order to state a framework which will enable us to better understand the following discussion on both Eckhart's Treatise On Being, What Is, and Nothing (De esse, ente et nihilo) and the relationship between his two extant Commentaries on Genesis, that is, between the Expositio libri Genesis (which I will refer to in English as the Expositio on Genesis) and the Liber parabolarum Genesis (which English speaking scholars know as the Book of the Parables of Genesis).

Now, what is Eckhart's Three-Part Work? And which of his writings are to be considered as constitutive parts of this Work? First I shall try to answer these questions by analysing the extant General Prologue to the Three-Part Work (Prologus generalis in Opus tripartitum), which the four manuscripts I am taking here into consideration include and which was doubtless written by Eckhart himself.

\section{MEISTER ECKHART'S OPUS TRIPARTITUM}

\section{A. The General Prologue to the Three-Part Work}

In this General Prologue, Eckhart explains what he is about to do in his Opus tripartium. He first enumerates the three different parts which, as he writes, will constitute the work: «We should distinguish within the whole work three different main parts. The first part is a Work

11 Cf. Denifle, H. S., «Meister Eckeharts lateinische Schriften und die Grundanschauung seiner Lehre», Archiv für Literatur und Kirchengeschichte des Mittelalters, 2 (1886), pp. 417-615.

12 Cf. Sturlese, L., «Über die Entstehung und die Entwicklung von Eckharts Opus tripartitum», in LW, Vol. I/2, pp. VII-LVII, here pp. IX-XII.

13 Ibid., p. X.

14 Cf. Quero-Sánchez, A., «Estudio introductorio», in Maestro Eckhart, Sermones y lecciones sobre el capítulo 24,23-31 del Eclesiástico, ed. by A. Quero Sánchez, Pamplona, EUNSA, 2010, pp. 13-101, here pp. 51-53. See also note 18 below. 
of General Propositions, the second is a Work of Questions, [and] the third a Work of Commentaries [on the different books of the Bible]». ${ }^{15}$ Here Eckhart also says that to each one of these main parts should be given a proper Prologue, that is, he was about to write a Prologue to the Work of Propositions or Opus propositionum, another one to the Work of Questions or Opus quaestionum, as well as a third Prologue to the Work of Commentaries or Opus expositionum. ${ }^{16}$

The extant manuscripts however do not contain any work belonging to the second of the announced parts, that is, neither any disputed question nor the Prologue to the Work of Questions. We surely know of some disputed questions by Eckhart, to be more exact, of nine of them, contained in two different manuscripts (one in Avignon [City Library = Bibliotheque Municipale] Livree Ceccano, MS 1071] [with three questions] ${ }^{17}$ the other in Rome [Vatican Library, Codex Vaticanus Latinus 1086] [with six questions]), ${ }^{18}$ but they all are not presented here as a part of the Opus tripartitum but just as forming part of collections of questions disputed by different magistri of the University of Paris at the beginning of the $14^{\text {th }}$ century. My following analysis will not focus, however, on Eckhart's Work of Questions, but on the two other parts of the Three-Part Work, that is, on his Work of Propositions -to which the treatise On Being, What is, and Nothing was conceived (by Eckhart himself) to belong- and on the Work of Commentaries, which contains, so it seems, the two extant commentaries on Genesis by Eckhart (Expositio on Genesis and the Book of the Parables of Genesis).

\section{B. The Work of Propositions}

\section{Introduction}

In the General Prologue to the Three-Part Work, Eckhart also enumerates the titles of fourteen treatises he is about to write for the intended first part of the work, that is, for the Work of Propositions. ${ }^{19}$ The first one will be, he says, a treatise On Being and What Is as

15 Meister Eckhart, Prologus generalis in Opus tripartitum, n. 3, LW, Vol. I/1, p. 149,3-5 (Recensio CT); LW, Vol. I/2, p. 21,15-17 (Recensio L): Distinguitur [...] opus ipsum totale in tria principaliter. Primum est opus generalium propositionum, secundum opus quaestionum, tertium opus expositionum.

16 Ibid., n. 1, LW, Vol. I/1, p. 148,4 (Recensio CT); LW, Vol. I/2, p. 21,3f. (Recensio L): Singulis tamen tribus operibus sua specialia prooemia praemittentur.

17 These three questions were first edited both by M. Grabmann and by E. Longpré in 1927. Cf. Grabmann, M., Neuaufgefundene Pariser Quaestionen Meister Eckharts und ihre Stellung in seinem geistigen Entwicklungsgange, Munich, Verlag der Bayerischen Akademie der Wissenschaften, 1927 (Abhandlungen der Bayerischen Akademie der Wissenschaften. Philosophisch-historische Abteilung 32,7); Longpré, E., «Questions inédites de Maître Eckhart OP et de Gonzalve de Balboa OFM», Revue néo-scolastique de philosophie, 19 (1927), pp. 69-85. See also the historico-critical edition by B. Geyer, in LW, Vol. V, Stuttgart, Kohlhammer, 1936-2006, pp. 27-83 (Questions 1 to 3).

18 These six questions were first edited by M. Grabmann in the above, note 17, mentioned study. However, Grabmann considered only two of these questions as genuine works of Eckhart. This was also the opinion of B. Geyer, who therefore included just these two questions, edited as Questions 4 and 5, in his historico-critical edition (LW, Vol. V, pp. 72-83). Recently, Markus Vinzent managed to show that also the four questions Grabmann had considered as spurious should be seen as a genuine work of Eckhart; cf. Vinzent, M., «Questions on the Attributes (of God): Four Rediscovered Parisian Questions of Meister Eckhart», Journal of Theological Studies, NS, 63 (2012), pp. 156-186. These «newly rediscovered questions» have been meanwhile incorporated by L. Sturlese into the historico-critical edition of Eckhart's Works (Quaestiones Parisienses. Supplementum, in LW, Vol. I/2 pp. 453470 [Questions 6 to 9]). See also ibid., p. 488 (Magistri Echardi fragmenta Parisiensia, n. 4).

19 Cf. Meister Eckhart, Prologus generalis in Opus tripartitum, nn. 3-4, LW, Vol. I/1, pp. 149,6-151,1 (Recensio CT); LW, Vol. I/2, pp. 21,18-23,18 (Recensio L). 
well as on the opposite of this, that is, on Nothing (De esse et ente et eius opposito quod est nihil). ${ }^{20}$ However, none of these treatises mentioned by Eckhart, so it seems, are extant. Most scholars even think that Eckhart had not written any of them, although Eckhart himself occasionally refers to some of these treatises in his extant works, for example in his Sermons and Lectures on the Twenty-fourth Chapter of «Ecclesiasticus» to both the treatise On the Nature of Superior and Inferior Things (De natura superioris et inferioris) ${ }^{21}$ and the first of the aforementioned treatises, that is, the treatise On Being, What Is, and Nothing (De esse, ente et nihilo). ${ }^{22}$

\section{The Prologue to the Work of Propositions}

The only extant part of Eckhart's Work of Propositions, so it seems, is the Prologue to it: the Prologue to the Work of Propositions (Prologus in Opus propositionum). This is a quite extensive Prologue, which is comprised of 225 lines in the critical edition by Konrad Weiß.23 Such length is really noticeable. For Eckhart's Prologue to the Work of Commentaries -I mean the so-called First Prologue to the Work of Commentaries- is very short compared to that: it includes only 16 lines in the critical edition of Wei $\beta,{ }^{24}$ beginning as follows:

In the beginning, God made heaven and earth». It begins [hereby] the third main part of the Three-Part Work, namely the Work of Commentaries.

As the prologue (prooemialiter) should here first be noticed that $\left[\ldots . .{ }^{25}\right.$

\section{a. «As the Prologue» (prooemialiter): A problematic passage in Eckhart's so-called Prologue to the Work of Propositions}

Is there any reason justifying such a lengthy Prologue to the Work of Propositions as compared to the one written for the Work of Commentaries? I think there is actually an explanation for this, which is the following: Eckhart's so-called Prologue to the Work of Propositions is not a Prologue but rather the first treatise he had mentioned in the General Prologue to the Three-Part Work as intended for the Work of Propositions, that is, his treatise On Being, What Is, and Nothing.

I will try to substantiate this claim below, but let me first raise another question: why do scholars -all of them- speak here not of a «treatise» but of a «prologue»? The answer is

20 Ibid., n. 4, LW, Vol. I/1, p. 150,1 (Recensio CT); LW, Vol. I/2, p. 23,3 (Recensio L).

21 Id., Sermones et lectiones super Ecclesiastici c. 24,23-31, n. 13, in LW, Vol. II, ed. J. Koch and H. Fischer, Stuttgart, Kohlhammer, 1954-1992, p. 243,4f.: sicut diffuse patet in tractatu «De natura superioris».

22 Ibid., n. 53, LW, Vol. II, p. 282,9: sicut ex primo «Libro propositionum» declaratur.

23 Id., Prologus in Opus propositionum, n. 1, LW, Vol. I/1, ed. by K. Weiß, pp. 166,1-182,8 (Recensio CT). Cf. ibid., ed. by K. Weiß, pp. 41,33-47,30 (Recensio E); LW, Vol. I/2, ed. by L. Sturlese, pp. 21,1-57,5 (Recensio L).

24 Id., Prologus in Opus expositionum I, in LW, Vol. I/1, ed. by K. Weiß, p. 183,1-11; Cf. ibid., ed. by K. Weiß, p. 48,17-26 (Recensio E); LW, Vol. I/2, ed. by L. Sturlese, p. 59,1-11 (Recensio L). There is in addition another Prologue to this work: the so-called Second Prologue to the Work of Commentaries (Prologus in Opus expositionum II), LW, Vol. I/1, ed. by K. Weiß, pp. 183f. (= LW, Vol. II, pp. 321,1-322,8). We also have to mention here Eckhart's very long and elaborated Prologue to the Book of the Parables of Genesis (Prologus in Librum parabolarum Genesis), LW, Vol. I/1, ed. by K. Weiß, pp. 447,1-456,6 (Recensio CT); LW, Vol. I/2, ed. by L. Sturlese, pp. 333,1-336,26 (Recensio altera). On all these Prologues see pp. 273-285 below.

25 Id., Prologus in Opus expositionum I, n. 1, LW, Vol. I/1, p. 183,2-4 (Recensio CT); LW, Vol. I/2, p. 59,2-4 (Recensio L): «In principio creavit deus caelum et terram». Operis tripartiti pars tertia principalis, opus scilicet expositionum, incipit. // Ubi prooemialiter praenotandum quod [...]. 
surely the following: because Eckhart himself speaks at the beginning of this text of a «Prologue»:

It begins [hereby] the first part of the Three-Part Work, namely the Work of Propositions, whose first treatise is on Being, What Is, and on the opposite of this, which is Nothing. In order to be able to well understand what will be said below both in this treatise itself and in some others following it, some preliminary remarks should be stated before as the Prologue (quaedam prooemialiter sunt praenotanda). ${ }^{26}$

In the immediately following passages, Eckhart discusses then these here announced «preliminary remarks» or praenotanda that «should be stated as the Prologue» or prooemialiter. And he discusses two praenotanda, namely the following:

First: In the same way as [the expression] «white» signifies only the quality [characterising things which are white], as Aristotle says, so also [the expression] «being» signifies only being [as the common «property» characterising things which «are»]. ${ }^{27}$

\section{$[\ldots]$.}

The second preliminary remark is the following: There is a difference between «being [in an absolute manner]» and «being in a certain [or determined] manner»..$^{28}$

I think it is quite clear that these two preliminary remarks constitute the-short- Prologue to both the Work of Propositions as a whole and the first treatise of this work, that is, to the treatise On Being, What Is, and Nothing. For Eckhart explicitly says, as we have quoted above, that these two preliminary remarks «should enable us to well understand what it will be said below both in this treatise» (that is, in the treatise, as he had just said, «on Being and What Is, and on the opposite of this, which is Nothing») «itself and in some others following it».

But the question I raised above still remains unanswered: why do scholars -all of them, without any exception- call not only these two preliminary remarks but also the following text as a whole the Prologue to the Work of Propositions? Surely -again- because Eckhart himself introduces «as a Prologue» (prooemialiter) not only the passages we have just discussed ( $\$ \S 2$ and 3), but also the following ones, the whole work. Let me quote $\S 4$ as the immediate continuation of the passages I have just discussed:

We have therefore to notice as the Prologue (Notandum ergo prooemialiter) first that God alone is, is a unity, is true and is good [in the proper sense]; second that because of God all things are, are a unity, are true and are good; third that immediately because of God all things are, are a unity, are true and are good; fourth that if I say: «this being thing», or «this unity» (or «this unity there»), or «this true thing» (or «this true thing there»), «this good thing» (or «this good thing there»), then the expressions «this» and «this [...] there» do not signify any aspect in virtue of which things were more [or better] than when they just are [in the absolute sense of the expression] nor in virtue of which they were more [or better] a unity than when they just are a unity [in the absolute sense

26 Id., Prologus in Opus propositionum, n. 1, LW, Vol. I/1, p. 166,2-5 (Recensio CT); LW, Vol. I/2, p. 41,2-5 (Recensio L): Incipit pars prima tripartiti, operis scilicet propositionum, cuius primus tractatus est de esse et de ente et de eius opposito, quod est nihil. Ad evidentiam igitur dicendorum in hoc tractatu et pluribus sequentibus quaedam prooemialiter sunt praenotanda.

27 Ibid., n. 2, LW, Vol. I/1, p. 166,6f. (Recensio CT); LW, Vol. I/2, p. 41,6f. (Recensio L): Primum est quod sicut album solam qualitatem significat, ut ait philosophus, sic ens solum esse significat.

28 Ibid., n. 3, LW, Vol. I/1, p. 166,12f. (Recensio CT); LW, Vol. I/2, p. 41,12f. (Recensio L): Secundo praenotandum quod aliter sentiendum est de ente et aliter de ente hoc et hoc. 
of the expression], nor in virtue of which they were more truthful than when they just are truthful [in the absolute sense of the expression], nor in virtue of which they were better than when they are good [in the absolute sense of the expression]. ${ }^{29}$

Eckhart's discussion of these four theses, which are explicitly introduced here -again- «as the Prologue» (prooemialiter), actually constitutes the whole text that follows, which is known as Eckhart's Prologue to the Work of Propositions. Now, this «prooemialiter» -to be more exact: this second «prooemialiter», because Eckhart had already used this expression, as we have seen above, a few lines before, when introducing the first two «preliminary remarks»- seems suspicious to me. How can it be, that only a few lines after he has discussed two «preliminary remarks» «as the Prologue» (quaedam prooemialiter sunt praenotanda), he announces four further remarks to be discussed -again- «as the Prologue» (Notandum ergo prooemialiter)?

In order to answer this question let us take a look at the paragraphs in which each of these four further remarks are introduced by Eckhart in his subsequent discussion:

The first of the four [above announced] remarks, namely that God alone in a proper sense is $[\ldots] . .^{30}$

$[\ldots]$.

The second of the four [above announced] remarks, namely that everything is, is a unity, is true and is good [in the absolute sense of these expressions] just because of God $[\ldots]^{31}$

$[\ldots]$.

And this is the third of the four main remarks which were announced above (Et hoc est tertium principale inter quattuor superius praemissa), namely that all being things -each of them- not only have received but also have immediately received (that is, without any mediation at all) their entire being, their entire unity, their truth as well as their entire goodness. ${ }^{32}$ [...].

A thing does not get a more perfect being, nor a more perfect unity, nor it becomes more true, nor better, because of its being «this» or «that» thing, «this» or «that» unity, «this» or «that» true thing, «this» good thing or «this» good thing «there». And this is the fourth of the four main remarks which were announced above (Et hoc est quartum principale supra praemissum) ${ }^{33}$

29 Ibid., n. 4, LW, Vol. I/1, pp. 167,9-168,5 (Recensio CT); LW, Vol. I/2, p. 43,1-6 (Recensio L): Notandum ergo prooemialiter primo quod solus deus proprie est ens, unum, verum et bonum. Secundo quod ab ipso omnia sunt, unum, vera sunt et bona sunt. Tertio quod ab ipso immediate omnia habent quod sunt, quod unum sunt, quod vera sunt et quod bona sunt. Quarto: quod cum dico hoc ens aut unum hoc aut unum illud, verum hoc et illud, bonum hoc et illud, li hoc et illud nihil prorsus addunt seu adiciunt entitatis, unitatis, veritatis aut bonitatis super ens, unum, verum, bonum.

30 Ibid., n. 5, LW, Vol. I/1, p. 168,6 (Recensio CT); LW, Vol. I/2, p. 43,7 (Recensio L): Primum inter quattuor, scilicet quod solus deus proprie est ens [...].

31 Ibid., n. 9, LW, Vol. I/1, p. 170,14f. (Recensio CT); LW, Vol. I/2, p. 45,10f. (Recensio L): Secundo inter quatuor, scilicet quod a solo deo omnia habent esse, unum esse, verum esse, bonum esse [...].

32 Ibid., n. 13, LW, Vol. I/1, pp. 172,14-173,10 (Recensio CT); LW, Vol. I/2, p. 47,11-14 (Recensio L): Et hoc es tertium principale inter quattuor superius praemissa, scilicet quod omne ens et singulum non solum habet, sed et immediate, absque omni prorsus medio, habet a deo totum esse, totam suam unitatem, veritatem et totam suam bonitatem.

33 Ibid., n. 15, LW, Vol. I/1, p. 176,3-5 (Recensio CT); LW, Vol. I/2, p. 49,23-25 (Recensio L): Nihil ergo entitatis, unitatis, veritatis et bonitatis penitus addit sive confert ens hoc aut hoc, unum hoc aut hoc, verum hoc aut illud, bonum hoc aut illud, in quantum hoc vel illud. Et hoc est quartum principale suprae praemissum. 
With regard to the third and the fourth remarks, Eckhart uses, as we see, the expressions tertium principale respectively quartum principale, meaning «the third» (and «the fourth») «of the four main remarks announced above». These remarks - of course not only the third and the fourth but also the first and the second- are therefore to be seen not as merely «preliminary remarks» functioning «as the Prologue» but as the main points or aspects constituting the main structure of the text, that is, these differentiations in four points or aspects actually constitute the main division of the whole text. Medieval authors -among them, of course, also Eckhart himself- use the adverb principaliter in order to introduce such a main division of the text. ${ }^{34}$ And I think this is the word which Eckhart had originally written, which was thereafter misunderstood or misread by some copyist, by reading -and copying- here not principaliter but prooemialiter, obtaining thereby this «second» prooemialiter. Actually, in the manuscript of Erfurt (E) we do not find the adverb prooemialiter but we read, as the editor Konrad Weiß himself did, ${ }^{35}$ perhennaliter, that is, «for eternity» (perennaliter):

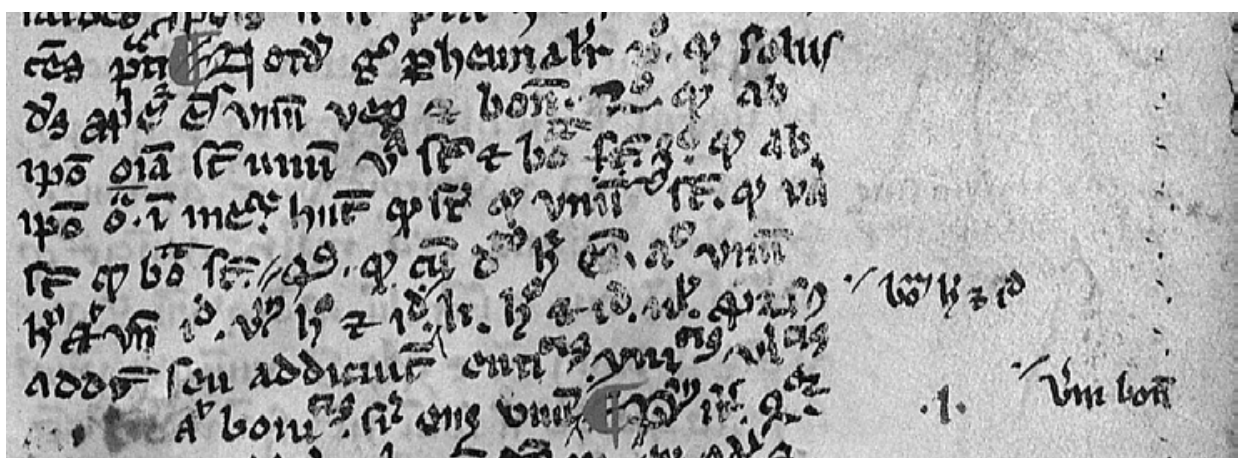

Erfurt/Gotha, University and Research Library (Universitäts- und Forschungsbibliothek), Department Erfurt, Codex Amplonianus F 181 (Sigle E), col. 6,28-35: Notandum ergo perhennaliter primo quod solus deus proprie est ens, unum, verum et bonum; secundo quod ab ipso omnia sunt unum, vera sunt et bona sunt; tertio quod ab ipso omnia immediate habent quod sunt, quod unum sunt, quod vera sunt, quod bona sunt; quarto quod cum dico hoc est, aut unum hoc aut unum illud, verum hoc et illud, bonum hoc et illud [in margine], li hoc et illud nihil prorsus addunt seu addicunt entitatis, unitatis, veritatis aut bonitatis super ens, unum, verum, bonum [in margine]..$^{36}$

This is, of course, a false reading of some anonymous copyist; it shows clearly, however, that this passage was from the beginning a problematic one, which later copyists tried to resolve by writing prooemialiter.

34 See for example Meister Eckhart, Expositio libri Genesis, n. 194, LW, Vol. I/1, ed. by K. Weiß, p. 340,1-7 (Recensio CT); LW, Vol. I/2, p. 223,15-22 (Recensio L): «Erant duo in carne una». Quamvis communiter hoc exponatur ad litteram et bene, quod vir et mulier sunt «duo in carne una», quia uniuntur quantum ad opus carnalis generationis [...], sunt tamen circa verba praemissa quinque principaliter consideranda, ex quorum singulo patebit quam convenienter dictum sit quod in natura humana mas et femina sunt «duo in carne una».

35 Cf. LW, Vol. I/1, p. 42,15 (footnote: «15 prohemialiter $C T$, perhennaliter $E »)$.

36 My own transcription; cf. Meister Eckhart, Prologus in Opus propositionum, n. 4, LW, Vol. I/1, p. 42,1521 (Recensio E). 


\section{b. Sicut ex primo Libro propositionum declaratur: Eckhart's Reference to the «first Book [of the Work] of Propositions» in his Sermons and Lectures on the Twenty- fourth chapter of «Ecclesiasticus»}

The best argument for supporting my claim that the text hitherto known as Eckhart's Prologue to the Work of Propositions is actually his treatise On Being, What Is, and Nothing can be found in Eckhart's Sermons and Lectures on the Twenty-fourth Chapter of «Eclesiasticus». He explicitly refers there to this treatise, which he calls now «the first Book of the Propositions» (primus Liber propositionum), meaning thereby, of course, «the first Book of [the Work of] Propositions». And he is referring thereby, as my following discussion will show, even to the text hitherto known as Prologue to the Work of Propositions.

Eckhart is arguing in the relevant passage of his second Lecture on the Twenty-fourth Chapter of «Ecclesiasticus», when interpreting Eccl. 24,29 («They that eat me, shall yet hunger» [Qui edunt me, adhuc esuriunt]), for his characteristic understanding of the doctrine of the analogy of being, which he is clearly formulating as opposed to that of the aristotelian-realistic metaphysics, as we find it, for example, in Albert the Great, Thomas Aquinas, Siger of Brabant or Godfrey of Fontaines. ${ }^{37}$ At the end of his discussion, he sums up his results as follows:

Let us sum up the argument and formulate it briefly as follows: Things of which a predicate «p» is predicated in an analogical sense do not contain rooted in themselves in a positive manner the form $p$, according to which they are said to be in an analogical sense «p». Now, any created thing is said «to be», «to be true» and «to be good» in an analogical sense, [namely] insofar as it is referred to God [in which alone «being» is rooted in a positive manner]. Therefore, any created thing has -considered as a [merely] created thing- not in itself rooted in a positive manner its being, its life [and] its knowledge, so that it, considered [merely] as something produced and created, is always lacking something else as well as always having need of something else; for it is not by itself but just because of something else.

We also have to notice here that some authors, having not rightly understood what it really means to say that «a thing is in an analogical sense $p$ », have been understanding this doctrine [of the analogy of being] in a false manner until now. But we understand the analogy [of being] according to the true doctrine, as it was explained in the first Book [of the Work] of Propositions. We say then that the verses [i.e. Eccl. 24,29] state in a completely correct manner that «they who eat me, shall yet hunger», expressing thereby this right meaning of the analogy, according to which every thing is said in an analogical sense «to be» [«to be true», «to be good»], [namely insofar as it is referred to God]. Beings are eating of something -insofar as they «are»-; but they are [at the same time] -insofar as they are just because of something else- lacking of something else. ${ }^{38}$

I have given here a -partly- free translation of the passage, in order to clarify the structure of Eckhart's argumentation in it. Eckhart's proof presents two premises followed by the conclusion. Let us analyse all these three steps separately.

37 For an extensive discussion on this see Quero-Sánchez, Über das Dasein (2013), pp. 664-704.

38 Meister Eckhart, Sermones et lectiones super Ecclesiastici c. 24,23-31, n. 53, LW, Vol. II, p. 282,1-12: Colligatur et formetur breviter sic ratio: analogata nihil in se habent positive radicatum formae secundum quam analogantur. Sed omne ens creatum analogatur deo in esse, veritate et bonitate. Igitur omne ens creatum habet a deo et in deo, non in se ipso ente creato, esse, vivere, sapere positive et radicaliter. Et sic semper edit, ut productum est et creatum, semper tamen esurit, quia semper ex se non est, sed ab alio. // Notandum etiam quod hanc naturam analogiae quidam male intelligentes et improbantes erraverunt usque hodie. Nos autem secundum veritatem analogiae intelligendo, sicut ex primo «Libro propositionum» declaratur, dicamus quod ad significandum hanc veritatem analogiae rerum omnium ad ipsum deum dictum est optime: "qui edunt me, adhuc esuriunt». Edunt, quia sunt, esuriunt, quia ab alio sunt. 
There is first the major-premise: Analogata nihil in se habent positive radicatum formae secundum quam analogantur. My translation of this («Things of which a predicate $\langle\mathrm{p}>$ is predicated in an analogical sense do not contain rooted in themselves in a positive manner the form $p$, according to which they are said to be in an analogical sense 〈p»») depends upon what Eckhart had explained in a paragraph just before, by using an Aristotelian example (health, healthy):

For example: one and the same health which is in a [healthy] animated being-even this one- is in a [healthy] food and in a [healthy] urine. This is the case, however, not insofar as health itself is in the [healthy] food and in the [healthy] urine-for in these both [that is, in a healthy food and in a healthy urine] is health itself just as little as it is in a stone. But this is only the case insofar as these both [that is, a healthy food and a healthy urine] mean [or refer to] even this same health which is itself [only] in a [healthy] animated being. In the same way, a circle [which in the Middle Ages used to be put at the door of a pub where it was possible to get some wine] means [that you can get there] wine, although there is nothing in a circle having anything to do with wine. ${ }^{39}$

This is, of course, the crucial premise for Eckhart's argument, based on an Aristotelian example, with Eckhart interpreting it, however, in a non-Aristotelian sense. ${ }^{40}$ For Aristotle uses this example to make it clear that there are many different ways that things can be said to be «healthy», although he, as he stresses at the same time, is not questioning thereby that there is just one health as the fundamental reason making all these different ways to be different ways to be «healthy». In contrast, Eckhart insists on the fact that health as such is only in one of the «things» that we call «healthy» (in the healthy animated being), whereas we call other things «healthy» (for instance some kind of food, or some kind of urine) not because health itself is in them, but only insofar as they mean or refer to the only «thing» being «healthy» by itself: because a certain kind of food contributes to the health of an animated being we call it a «healthy food»; and because a certain kind of urine is a sign of a healthy animated being we call it a «healthy urine».

The minor-premise then follows (Sed omne ens creatum analogatur deo in esse, veritate et bonitate) («Any created thing is said 〈to be〉, 〈to be true〉 and 〈to be good〉 in an analogical sense, [namely] insofar as it is referred to God [in which alone «being» is rooted in a positive manner]»). This premise simply expresses a thesis which was commonly accepted at that time -at least by all Aristotelian thinkers, like Albert the Great, Siger of Brabant, Thomas Aquinas or Godfrey of Fontaines-, according to which «being» is not said of God and the creatures in a univocal, nor equivocal, but in an analogical sense. Now, what does this mean for an Aristotelian thinker, for example for Albert the Great? Albert uses the adverb analogice as a synonym for proportionaliter. ${ }^{41}$ Any existing thing «is», Albert says, just insofar as it brings

39 Ibid., n. 52, LW, Vol. II, pp. 280,9-281,5: Verbi gratia: sanitas una eademque, quae est in animali, ipsa est, non alia, in diaeta et urina, ita quod sanitatis, ut sanitas, nihil prorsus est in diaeta et urina, non plus quam in lapide, sed hoc solo dicitur urina sana, quia significat illam sanitatem eandem numero quae est in animali, sicut circulus vinum, quia nihil vini in se habet. Ens autem sive esse et omnis perfectio, maxime generalis, puta esse, unum, verum, bonum, lux, iustitia et huiusmodi, dicuntur de deo et creaturis analogice. Ex quo sequitur quod bonitas et iustitia et similia bonitatem suam habent totaliter ab aliquo extra, ad quod analogantur, deus scilicet.

40 See on this Quero-Sánchez, Sein als Freiheit (2004), pp. 96f., with note 182 referring to the different occurrences of this example in Aristotle, Thomas Aquinas and Meister Eckhart. See also id., Über das Dasein (2013), p. 667, note 2421 (On Albert the Great) and pp. 687-689 (On Godfrey of Fontaines). On Siger of Brabant see id., «Individuum, Modernität und Aufklärung im Denken Meister Eckharts und Sigers von Brabant», in Fr. Löser and D. Mieth (eds.), Religiöse Individualisierung in der Mystik (2014), pp. 11-53, here pp. 40-47.

41 See the discussion in Quero-Sánchez, Über das Dasein (2013), pp. 664-668 («Das Verhältnismäßigkeitsprinzip»). 
about the natural way of being which was -and still is- given to it by God, its creator. There is therefore not just a single way of being -the divine or absolute one- which everything would have to have in order to (in a proper or divine sense) «be», but there are various ways in which things can be said to (in a proper or divine sense) «be». This variation now depends on the particular nature of every thing, given to it by God through the act of creation. «To be a man» does not mean the same as «to be a horse», but by his being-a-man a particular man is bringing about his «being» (in the proper or absolute sense of the word), just as a horse is bringing about its «being» (in an absolute sense of this word) simply by its being-a-horse. «To be» in an absolute or divine manner (esse absolute seu simpliciter) is not different from «to be in a particular [or determined] manner» (esse hoc vel illud). There are therefore various ways how things can be said to «be», but this variety represents at the same time a unity, because there is just one efficient cause -God-for the existence of such a variety. ${ }^{42}$

Siger of Brabant and Godfrey of Fontaines, who both understand this doctrine of the analogy of being in a similar way to Albert the Great, speak in this context of an identity of being (esse) and essence (essentia). ${ }^{43}$ Here «essence» means the particular way of being of things, which is defined by their proper «form»: the form of man defines, for instance, what man is, its «nature», which is, of course, different from what -let us say- a horse is. The thesis of the identity of «essence» and «being» means therefore that things are just what they -considered as defined or even determined by their natural form- are. The form of the thing, which is rooted «in» the thing itself, differentiating this thing -for instance a man- from other ways of being -for instance from being-a-horse-, defines therefore what things really «are». The form can, of course, imply -and actually (mostly) implies - a reference to matter as a constitutive element of a particular way of being; in the case of man, for instance, to a body making it possible to be-aman, that is, to exist or to be there as a man. To sum up: things «are» even what they are «being by themselves», because their essentia (defined by their form, which is not to be seen as opposed to the material constitution of things) constitutes their esse. Of course, a thing is not by itself with regard to its existence, which was -and, in a sense, still is-given to it by God by creating it from nothing. That is the reason why we do not have to refer this thesis of the identity of essence and being, as Siger of Brabant explicitly points out, to the existence of the thing but only to its essential being: a thing cannot bring itself into existence, but nonetheless it is nothing else than what it itself -in virtue of its own form rooted in itself-is:

We have to say to this that in this [Avicennian] answer [stating that things are not «because of» (or «by») (ex) themselves] the expression «because of» [or «by»] (ex) is used ambiguously [ = in an equivocal sense]. It has a causal meaning, but there are different ways in which something can be a cause, as is shown in the fifth book of the Metaphysics [of Aristotle]. And Avicenna made a mistake here, by confusing one meaning of the expression «because of» [or «by»] (ex) with another one. For when we say «a thing is by [or because of] itself», this expression, «by» [or «because of»], can mean both the formal and the efficient cause. My claim is the following: man is «by himself» if this «by» means the formal cause; nonetheless man is «by [or because of] something else»

42 Cf. ibid., pp. 668-675 («Das Seinlassen vorgegebener Verschiedenheit»), and pp. 675-679 («Alberts aristotelische Umformung der Metaphysik: die moderne Promotion des Konkreten»).

43 Cf. ibid., pp. 181-207; id., «Individuum, Modernität und Aufklärung» (2014), pp. 19-24; id. «Der mittelalterliche Disput zwischen Realismus und Idealismus: Meister Eckhart, Gottfried von Fontaines und Marguerite Porete», in D. Mieth, M. Vinzent, M. -A. Vannier and C.M. Wojtulewicz (eds.), Meister Eckhart in Paris and Strasbourg, Leuven, Peeters, 2017 (Meister Eckhart: Texts and Studies 4), chapter 3.2 («Die Frage nach dem Wirklichsein des Realen») (in press). You will find in all these studies numerous references to the relevant passages in the works of both Siger and Godfrey. 
[because of something else, namely because of God as his creator] if this «by» means the efficient cause. This was the error [of Avicenna]. That is the reason why [Aristotle] says in the Posterior Analytics that the first meaning of the expression «by itself» [<because of itself〉] (per se) is that a thing is 〈by> [or 〈because of ] its [own] form». Something can therefore be caused by itself -meaning the formal cause-, which has, however, an efficient cause being different from this thing itself. ${ }^{44}$

This passage means that the thesis of the identity of being and essence is not to be applied to the existence of things, which, Siger says, was given to them -and, in a certain sense, is still being given to them now and as long as they keep existing- by God as their efficient cause. This is even the position of both Albert the Great and Thomas Aquinas ${ }^{45} \mathrm{Of}$ course, the essence of a thing would not «be» or «exist» -unless merely as a thought of God-, if God had not had created this thing. And this is the reason why both for Albert the Great and for Thomas Aquinas essence and being are not identical but «really different»: because even the essence as that what a thing is «by itself» (ex se or per se) is ultimately given -by God- to the thing, which, without this creative action of God as its efficient cause bringing it into existence, would be pure nothing. According to all the aforementioned Aristotelians -that is, according to Albert the Great as well as Thomas Aquinas, Siger of Brabant and Godfrey of Fontaines- the following thesis is correct: given (because of the creative action of God) the world, a thing is what it really is just «by», «because of» or even «in virtue of» its own form, that is, in virtue of the form which is rooted in this thing itself. And this is too the -Aristotelian- thesis Eckhart is criticising with his particular interpretation of the analogy of being which has been explained above. Let me quote the conclusion of his argumentation again:

Therefore, any created thing has -considered as a [merely] created thing- not in itself rooted in a positive manner its being, its life [and] its knowledge, so that it, considered [merely] as something produced and created, is always lacking something else as well as always having need of something else; for it is not by itself but just because of something else. ${ }^{46}$

This thesis is, of course, also true for Albert the Great and Thomas Aquinas, but not in the same sense as Eckhart is stating it. According to Aristotelian thinkers, things «are» in virtue of their own forms, which are rooted in the things themselves. But even after they have been created by God, things are, according to Eckhart, not in virtue of their own forms, but only insofar as they are referred to God as to the one «thing» being by itself or in an absolute manner. By its «being-itself» a thing is not being what it itself really is, but this «thing» has to

44 Siger of Brabant, Quaestiones in Metaphysicam, ed. by W. Dunphy, Quaestiones in metaphysicam. Édition revue de la reportation de Munich. Texte inédit de la reportation de Vienne, Louvain-la-Neuve, Éditions de l'Institute Supérieur de Philosophie, 1981 (Philosophes Médiévaux 25), p. 44,96-106 (reportatio of Munich): Dicendum quod hic est aequivocatio ex eo quod «ex» importat circumstantiam causae, et causa multipliciter dicitur, ut habetur $V^{\circ}$ «Metaphysicae»; et Avicenna deceptus fuit per aequivocationem de ly «ex». Cum enim dicitur «res est ex seipsa», potest «ex» denotare circumstantiam causae formalis vel efficientis. Tunc dico quod ista simul stant: homo est homo per se, secundum quod ly «per» dicit circumstantiam causae formalis; et tamen homo per aliud est homo secundum quod «per» denotat circumstantiam causae efficientis; et sic est hic deceptio. Unde in libro «Posteriorum»: primo modo dicendum «per se», illud est tale quod est tale per suam formam: unde potest aliquod causatum esse per se formaliter, et tamen causam efficientem habet aliam.

45 Cf. Quero-Sánchez, Über das Dasein (2013), pp. 155-164; id., «San Alberto Magno y el Idealismo Alemán de la Edad Media Tardía (Maestro Eckhart y Teodorico de Freiberg)», Revista española de filosofía medieval, 18 (2011), pp. 95-122, here pp. 109-113.

46 See above, p. 267. 
let God -as Being itself or Absolute Being (esse est deus)- be in it, in order to be what it itself really is. Things have not to be by themselves, in order to (in a proper or divine sense) «be». Now, by their «being-not-by-themselves» things are -paradoxically- realising what they themselves (in the proper sense) «are» (esse absolute), as Eckhart himself puts out in his Talks of Instruction: «Right, the more we ourselves are, the less are we ourselves (= the less are we [in a proper sense])» (Jâ, ie mer wir eigen sin, ie minner eigen). ${ }^{47}$

After he has summed up his argumentation in the form explained above, Eckhart refers to -as he calls it- the «first Book of Propositions», that is, to the «first Book of the Work of Propositions», meaning his treatise On Being, What is, and Nothing. Let me quote the relevant passage again:

We also have to notice here that some authors, having not rightly understood what it really means to say that «a thing is in an analogical sense $p$ », have been understanding this doctrine [of the analogy of being] in a false manner until now. But we understand the analogy [of being] according to the true doctrine, as it was explained in the first Book [of the Work] of Propositions. We say then that the verses [i.e. Eccl. 24,29] state in a completely correct manner that «they who eat me, shall yet hunger», expressing thereby this right meaning of the analogy, according to which every thing is said in an analogical sense «to be» [«to be true», «to be good»], [namely insofar as it is referred to God]. Beings are eating of something -insofar as they «are»-; but they are [at the same time] -insofar as they are just because of something else- lacking of something else. ${ }^{48}$

This is clearly the metaphysical position Eckhart is maintaining in the hitherto called Prologue to the Work of Propositions, which is actually not the Prologue but the first treatise of this Work, namely Eckhart's hitherto thought-to-be-lost treatise On Being, What is, and Nothing. Let me quote -again- the passage in which Eckhart presents the main structure of the text, which makes particularly clear what I have just said:

We have therefore to notice as the Prologue (Notandum ergo prooemialiter) first that God alone is, is a unity, is true and is good [in the proper sense]; second that because of God things are, are a unity, are true and are good; third that immediately because of God things are, are a unity, are true and are good; fourth that if I say: «this being thing», or «this unity» (or «this unity there»), or «this true thing» (or «this true thing there»), «this good thing» (or «this good thing there»), then the expressions «this» and «this [...] there» do not signify any aspect in virtue of which things were more [or better] than when they just are [in the absolute sense of the expression] nor in virtue of which they were more [or better] a unity than when they just are a unity [in the absolute sense of the expression], nor in virtue of which they were more truthful than when they just are truthful [in the absolute sense of the expression], nor in virtue of which they were better than when they are good [in the absolute sense of the expression] ${ }^{49}$

And there are many other passages in the hitherto called Prologue to the Work of Propositions supporting my claim, for instance the following:

[It is the case] that God alone in the proper or absolute sense is, is a unity, [and] is good, whereas other being things are [just] in a particular [or determined] manner -by their beinga-stone, being-a-lion, being-a-man or something like this-, as well as a particular [or deter-

47 Meister Eckhart, Talks of Instruction, DW, Vol. V, ed. by J. Quint, Stuttgart, Kohlhammer, 1954-1963 (repr. 1987), p. 230,8.

48 See above, p. 267.

49 See above, p. 265. 
mined] unity, or true in a particular [or determined] manner, or good in a particular [or determined] way, by being, for example, a good spirit, a good angel or something like this. ${ }^{50}$

This is even the position Eckhart is expressing with his particular understanding of the doctrine of the analogy of being in his Sermons and Lectures on the Twenty-fourth Chapter of «Ecclesiasticus», as we have seen above. And we also find in the hitherto called Prologue to the Work of Propositions, of course, some passages in which Eckhart explicitly says that the particular being of things (esse hoc), which they have «because of», «by» or «in virtue of» their own forms rooted in them themselves, is not giving to these things their «being» (in the proper, divine or absolute sense of this word) (esse absolute):

By maintaining this thesis, we are not eliminating the secondary causes nor their influences. For the form of fire does not give to a fire its being [in an absolute sense], but it gives to it [nonetheless] a particular manner of being: its being-fire; it does not give to a fire its being a unity [in an absolute sense], but it gives to it [nonetheless] its being a particular unity, a particular [or concrete] fire. The same is the case with beingtrue and being-good. Now, even this -I mean that the form of fire gives to a fire its [particular manner of] being, its being a [particular or concrete] unity, its being-true [in a particular manner] and its being-good [in a particular manner]- all this is only insofar the case as the first cause gives to [this particular manner of being which is] being-fire its stability, according to what is said in the Book of the Causes: that «the stability and the essence of any rational being comes about because of the pure goodness, which is the First Cause», as well as in the commentary on this thesis in even this Book. ${ }^{51}$

Now, if my thesis -that Eckhart's hitherto called Prologue to the Work of Propositions is really the hitherto thought-to-be-lost treatise On Being, What is, and Nothing- is right, then the last sentence of this work was not written by Eckhart himself but by an anonymous editor after he has brought all these texts -I mean: the General Prologue, the (so-called) Prologue to the Work of Propositions, the Prologue to the Work of Commentaries (I) and (at least) the Expositio on Genesis - together: "After we have explained these aspects in order to be able to better understand what we are about to say in what follows, let us begin with the treatise and say: "Being is God, etc."». ${ }^{52}$ The anonymous editor thus, having red prooemialiter (insteed of principaliter), interpreted the whole text not as the first treatise of the Work of Propositions but as the Prologue to it, adding -and this is the case in all known versions of the text (E, L and CT) - the just quoted sentence at the end of the work, ${ }^{53}$ which

50 Meister Eckhart, Prologus in Opus propositionum, n. 8, LW, Vol. I/1, p. 170,10-13 (Recensio CT); LW, Vol. I/2, p. 45,6-9 (Recensio L): [...] quod solus deus est ens, unum, verum, bonum proprie, reliquorum autem singulum est ens hoc, puta lapis, leo, homo et huiusmodi, et unum hoc, verum hoc, bonum hoc, puta bonus animus, bonus angelus et huiusmodi.

51 Ibid., n. 11, LW, Vol. I/1, pp. 171,14-172,5 (Recensio CT); LW, Vol. I/2, pp. 45,24-47,3 (Recensio L): Nec tamen per hoc excluduntur causae secundariae a suis influentiis. Forma enim ignis non dat igni esse, sed esse hoc, nec esse unum, sed esse unum hoc, puta ignem et unum ignem. Similiter de vero et bono. Sed et hoc ipsum, puta quod forma ignis dat esse ignem, unum, verum, bonum, habet per fixionem causae primae, iuxta illud Libri de causis: «omnis intelligentiae fixio et essentia est per bonitatem puram, quae est causa prima» et in commento ibidem.

52 Ibid., n. 25, LW, Vol. I/1, p. 182,7f. (Recensio CT); LW, Vol. I/2, p. 57,3f. (Recensio L): His igitur ad evidentiam dicendorum praemissis incipiamus et dicamus: Esse est deus etc. This passage is already contained in the earliest version of the work, as we find it in the Erfordian manuscript (L), LW, Vol. I,1, p. 47,29f. (Recensio E).

53 The Oxonian manuscript (L) still adds a further sentence here; cf. ibid., n. 25, LW, Vol. I/2, p. 57,5 (Recensio L): «To this should immediately follow the work or book containing the Work of Propositions» (Isti immediate debet continuari opus propositionum sive liber). 
is nothing but a collection of information he had found in two earlier passages in the manuscript. The first passage is the beginning of the hitherto called Prologue to the Work of Propositions: «In order to be able to well understand what I will say below both in this treatise itself and in some others following it, some previous remarks should be stated before as the Prologue». ${ }^{54}$ The second passage is the paragraph n. 11 of the General Prologue to the Three-Part Work:

In order to show -with an example- what kind of method I will use in the entire Three-Part Work, I will carry out here, as a sort of Prologue, the proof of the first proposition, I will also discuss the first question as well as interpret the first verse of the Bible.

The first proposition is: Being is God. ${ }^{55}$

What is important to emphasise for the following discussion is the fact that we can observe in Eckhart's Three-Part Work the efforts of -at least- one anonymous editor for presenting Eckhart's Latin works as -at least to some degree- a coherent whole. This is, as it seems, already the case with the earliest extant version of the work, as we find it in the Erfordian manuscript (E). And we will see that this is the case not only with regard to the so-called Prologue to the Work of Propositions, but also with Eckhart's commentaries on Genesis.

\section{The Work of Commentaries}

All the aforementioned manuscripts of the Opus tripartitum (E, L, T and C) also contain along with the discussed Prologues as well as other works by Eckhart- the Expositio on Genesis, indeed even four different versions of it, as we see in the following table:

\section{E (Erfurt)}

$\varnothing$

\section{L (Oxford)}

$\varnothing$

General Prologue

Prologue to the Work of Propositions (that is, the treatise On Being, What Is and Nothing)

Prologue to the Work of Commentaries (I)

\section{C/T (Kues and Trier)}

Table of Contents referring to the Prologues (that is, both the General Prologue and the so-called Prologue to the Work of Propositions [that is, the treatise On Being, What is, and Nothing]) and to the Expositio on Genesis

54 Ibid., n. 1, LW, Vol. I/1, p. 166,4f. (Recensio CT); LW, Vol. I/2, p. 41,4f. (Recensio L): Ad evidentiam igitur dicendorum in hoc tractatu et pluribus sequentibus quaedam prooemialiter sunt praenotanda. See above, p. 266.

55 Id., Prologus generalis in Opus tripartitum, n. 11, LW, Vol. I/1, 156,7-11 (Recensio CT); LW, Vol. I/2, 29,9-12 (Recensio L): Ut autem hoc exemplariter sit videre et habeatur modus procedendi in totali opere tripartito, prooemialiter praemittemus primam propositionem, primam quaestionem et primae auctoritatis expositionem. // Prima propositio est: «Esse est deus». 


\section{E (Erfurt)}

Expositio on Genesis

(Recensio E [E1 and E2])
L (Oxford)

Expositio on Genesis

(Recensio L)

\section{C/T (Kues and Trier)}

Expositio on Genesis

(Recensio CT)

etc. ${ }^{58}$

The Erfordian manuscript (E) contains an earlier, yet uncompleted version of the Expositio on Genesis, which is known among scholars as «Recensio E». This version presents many important marginal additions in this manuscript, which, when taken together with the earlier version («Recensio E1»), constitute a new but still uncompleted «Recensio E2». ${ }^{59}$ We find in the Oxonian manuscript (L) a further extended version $\left(«\right.$ Recensio L»). ${ }^{60}$ Finally, the so-called «Recensio CT», which we find in both the manuscript of Kues (C) and of Trier (T), is similar to -but not identical with- the Oxonian version L. ${ }^{61}$ Both Konrad Weiß and Loris Sturlese consider this «Recensio CT» as (to a certain extent) resulting from the editorial action of some anonymous editor. ${ }^{62}$ And I am sure they are right with this hypothesis.

The second extant Commentary on Genesis by Eckhart, that is, his Book of the Parables of Genesis, is contained only in the manuscripts of Oxford (L), Kues (C) and Trier (T), but not in the Erfordian one (E). In the Oxonian manuscript (L), it precedes the Three-Part Work, whereas the anonymous editor of the «Recensio CT» presents it after the Expositio on Genesis, as if also it should be seen as a constituent part of the Three-Part Work, and therefore as Eckhart's «Second Commentary on Genesis». We have also in this case to distinguish a better text, contained in the Oxonian manuscript («Recensio L»), from the -let us say- «less better» one we find in both $\mathrm{C}$ and $\mathrm{T}(\ll$ Recensio $\mathrm{C} »)$ :

\section{L (Oxford)}

Prologue and Table of Contents of the Book of the Parables of Genesis

Book of the Parables of Genesis (Recensio L)

Alphabetical Register to the Book of the Parables of Genesis

\section{C/T (Kues and Trier)}

$\varnothing$ (but see below)

$\varnothing$ (but see below)

$\varnothing$

56 This manuscript (E) contains the following other works by Eckhart: Commentary on Exodus; Sermons and Lectures on the Twenty-Fourth Chapter of Ecclesiasticus; Prologue to the Work of Commentaries (II); Commentary on Wisdom; Table of Contents of the Commentary on Wisdom.

57 This manuscript also (L) contains other works by Eckhart; see below, p. 275.

58 These manuscripts also C and T contain other works by Eckhart; see below, p. 275.

59 Both these versions (Recensio E1 and Recensio E2) have been edited by K. Weiß, in LW, Vol. I/1, pp. 48, 26-96, 25. There are also some (but not many) marginal additions to the so-called Prologue to the Work of Propositions. Loris Sturlese thinks that the person who wrote these marginal additions took the new passages directly from the additions Eckhart himself had done in the meantime; cf. Sturlese, «Über die Entstehung und die Entwicklung», pp. XVIf. However, I think there is another possible and maybe more plausible explanation for this: the copyist compared the early version (E1) with a later one he had found in another, now lost manuscript containing E2, and wrote the missing passages in the margins of the manuscript E. As is well-known, such a procedure was not unusual in the Middle Ages.

60 Edited by L. Sturlese, in LW, Vol. I/2, pp. 59-329.

61 Edited by K. Weiß, in LW, Vol. I/1, pp. 185-444.

62 Cf. K. Weiß, in LW, Vol. I/1, pp. 107-110; Sturlese, «Über die Entstehung und die Entwicklung», pp. XXXIV-XLIV. 


\section{L (Oxford)}

$\varnothing$

General Prologue, Prologue to the Work of Propositions (that is, the treatise On Being, What is, and Nothing), and Prologue to the Work of Commentaries (I)

Expositio on Genesis

$\varnothing$ (but see above)

$\varnothing$ (but see above)

$\varnothing^{63}$

\section{C/T (Kues and Trier)}

Table of Contents referring to the Prologues (that is to both the General Prologue and the so-called Prologue to the Work of Propositions [that is, the treatise On Being, What is, and Nothing]) and to the Expositio on Genesis

$$
=
$$

\section{Expositio on Genesis (Recensio CT)}

Prologue and Table of Contents of the Book of the Parables of Genesis

Book of the Parables of Genesis (Recensio CT)

etc. ${ }^{64}$

Having said this, we are able to establish some probable conclusions with regard to the relationship between Eckhart's commentaries on Genesis:

- Eckhart's Expositio on Genesis is older than his Book of the Parables of Genesis. Why? Because the Erfordian manuscript (E), containing surely the earliest version of Eckhart's Latin works, does not know anything of it, although it also contains other biblical commentaries by Eckhart, namely a very early version of his Commentary on Exodus («Recensio E») ${ }^{65}$ as well as -both already completed-the Commentary on Wisdom $^{66}$ and Sermons and Lectures on the Twenty-Fourth Chapter of «Ecclesiasticus». ${ }^{67}$

- In contrast to what is the case with the Expositio on Genesis, the Book of the Parables of Genesis was not a constituent part of the Three-Part Work but an independent work, as we find it in the Oxonian manuscript (L), having been published, surely by Eckhart himself, with a very elaborated and extensive Prologue, a Table of Contents and even an Alphabetical Register put at the end of the whole work. ${ }^{68}$ That is surely

63 The Oxonian manuscript (L) does not contain any more works by Eckhart.

64 The manuscript of Trier (T) contains in addition also Eckhart's Commentary on Exodus (preceded by a Table of Contents of it). The manuscript of Kues (C) is the most complete one we know of Eckhart's Latin works. It was written in 1444, on behalf of Nicholas of Cusa. It contains in addition also the following works by Eckhart: Prologue to the Work of Commentaries (II); Commentary on Wisdom; Sermons and Lectures on the Twentyfourth chapter of Ecclesiasticus; Table of Contents of the Commentary on Wisdom; Table of Contents of the Commentary on John's Gospel; Commentary on John's Gospel; Treatise on the Lord's Prayer as well as a collection of Eckhart's Latin Sermons.

65 Both extant versions of Eckhart's Commentary on Exodus have been edited by K. Weiß; cf. LW, Vol. I/1, pp. 96,26-101,21 (Recensio E); LW, Vol. II, pp. 1-227 (Recensio CT).

66 Edited by J. Koch and H. Fischer, LW, Vol. II, pp. 303-634.

67 Edited by J. Koch and H. Fischer, LW, Vol. II, pp. 231-300.

68 Cf. Sturlese, L., «Tabula per alphabetum in librum Parabolarum Genesis, ritrovata e per la prima volta pubblicata da Loris Sturlese», in Scritti in onore di Eugenio Garin, Pisa, Scuola Normale Superiore, 1987, pp. 39-50, here p. 42: «Conclusione: la tabula è autentica, fu posta a conclusione di un Liber parabolarum concepito come opera autonoma, sostanzialmente al di fuori dell'Opus tripartitum, e fu eliminata da chi prese la decisione 
the reason why the work is not called an Expositio but a Liber, that is precisely a «Book», or a «Tractatus», that is a «Treatise». ${ }^{69}$

- A later, anonymous editor inserted the Book of the Parables of Genesis into Eckhart's Three-Part Work, as if it were a «Second Commentary on Genesis» within the Work of Commentaries (secunda editio super Genesim), following, as we find it in the «Recensio CT», the Expositio on Genesis as Eckhart's «First Commentary on Genesis» (prima editio Super Genesim). Since the Prologues (that is, both the General Prologue and the so-called Prologue to the Work of Propositions) and the Expositio on Genesis had not yet had any Table of Contents at this time - probably because all these works were not intended by Eckhart himself to be published in this form-, the anonymous editor of the «Recensio CT» added a Tabula Prologorum in Opus tripartitum and a Tabula auctoritatum Libri Genesis he himself had written before ${ }^{70}$ which are similar to the Table of Contents to the Book of the Parables of Genesis, which was surely made by Eckhart himself as he published this commentary as a «Book» (Liber). The anonymous editor of the «Recensio CT» removed thereafter, so it seems, the Alphabetical Register to the Book of the Parables of Genesis, which we still find in the Oxonian manuscript (L), avoiding thereby the surely not easy task of constructing a similar register for the Prologues and the Expositio on Genesis.

\section{III.THE RELATIONS HIP BETWEEN THE EXPOSITIO ON GENESIS AND THE BOOK OF THE PARABLES OF GENESIS}

However, the fundamental question still remains unanswered: Why did Meister Eckhart write two different commentaries on Genesis? What kind of relationship is there between Eckhart's Expositio on Genesis and his Book of the Parables of Genesis?

\section{A. The «classical» Answer}

The «classical» answer to this question is the following: In the Expositio on Genesis, Eckhart interprets the text primarily looking for its merely historical or literal sense, whereas in the Book of the Parables of Genesis he does it allegorically or, as he himself says in Latin, parabolice, that is, looking for the deep meaning of the text, which might be -and often actua-

di integrare il Liber nell'Opus in qualità di supplemento alla prima esposizione del Genesi». Cf. id., «Un nuovo manoscritto delle opere latine di Eckhart e il suo significato per la ricostruzione del testo e della storia dell'Opus tripartitum», in R. Imbach and Ch. Flüeler (eds.), Albert der Große und die deutsche Dominikanerschule. Philosophische Perspektiven, Fribourg (Swiss), Universitätsverlag, 1985, pp. 145-154, here p. 146. This Tabula has recently been published within the historico-critical edition of Eckhart's Latin Works by Sturlese himself; cf. LW, Vol. I/2, pp. 447-451.

69 Cf. Meister Eckhart, Expositio libri Genesis, n. 200, LW, Vol. I/2, p. 229,16f. (Recensio L): [...] de quibus plenius notavi in tractatu qui inscribitur «De parabolis rerum naturaliter». The «Recensio CT» speaks here not of a «Treatise» but of the «second Commentary on Genesis»; ed. K. Weiß, LW, Vol. I/1, p. 347,4f.: [...] de quibus plenius invenies in secunda editione «Super Genesim parabolice». See also Expositio libri Genesis, n. 288, LW, Vol. I/2, p. 309,13: Notavi de hoc plenius in tractatu «De parabolis rerum naturalium» (Recensio L); ibid., Vol. $\mathrm{I} / 1$, p. $424,1 \mathrm{f}$. (Recensio CT) (in this case, the text is the same).

70 Cf. K., Weiß, LW, Vol. I/1, p. 121. Weiß defends this position by arguing against the contrary opinion which H. Bascour had maintained in 1935; cf. Bascour, H., «La double rédaction du premier commentaire de Maître Eckhart sur la genèse», Recherches de théologie ancienne et médiévale, 7 (1935), pp. 294-320, here p. 319. 
lly is- quite different from its merely literal sense. ${ }^{71}$ Since a «parable» is for Eckhart an «allegory», it would be possible to translate the title of the Liber parabolarum Genesis with Book of the Allegories of Genesis. By using this allegorical method, he is not only depending upon Moses Maimonides, to whom he himself refers in the Prologue to this Book, ${ }^{72}$ but especially upon Origen of Alexandria, who is, also in other contexts, a crucial source for Eckhart. ${ }^{73}$ The allegorical interpretation of the biblical texts enables Eckhart to see them as expressing some important philosophico-theological theses, which at first glance - that is to say: when we read the texts just in their historical or literal sense- are not identifiable at all.

The «classical» answer to the question about the relationship between Eckhart's Commentaries on Genesis is actually, so it seems, the answer he himself has given to in the Prologue to the Book of the Parables of Genesis. Let me quote the very first sentence of this book:

After I have explained in the first commentary what, as it seemed to me, should be said concerning the manifest meaning of Genesis, my intention in this commentary of the parables [i.e. of the allegories] [...] is to work out some latent meanings which are allegorically contained (parabolice contenta) «under the skin of the litteral text». ${ }^{74}$

However, this «classical» answer cannot be right. First of all, because Eckhart is already using the allegorical method of interpretation in the Expositio on Genesis, not now and again or occasionally but even as the main method for understanding the texts. Yet, this allegorical method is precisely the one Eckhart uses to apply not only for its interpretation on Genesis but altogether, as he explains himself in the so-called «Second Prologue to the Work of Commentaries». This Prologue is contained in both the manuscript of Erfurt (E) and the one of Kues $(\mathrm{C})$, preceding in both cases Eckhart's Commentary on Wisdom. This Prologue was doubtlessly written by Eckhart himself. However, it is surely not a work defi-

71 See Beccarisi, «Eckhart's Latin Works» (2013), pp. 104f.

72 Cf. Meister Eckhart, Liber parabolarum Genesis, n. 1, LW, Vol. I/1, ed. by K. Weiß, pp. 448,6-449,3 (Recensio CT); LW, Vol. I/2, ed. by L. Sturlese, pp. 333,14-334,2 (Recensio altera).

73 On Eckhart's allegorical interpretation of the biblical texts see Quero-Sánchez, A., «Sermo XVII: Nunc vero liberati a peccato», in G. Steer and L. Sturlese (eds.), Lectura Eckhardi. Predigten Meister Eckharts von Fachgelehrten gelesen und gedeutet, Vol. III, Stuttgart, Kohlhammer, 2009, pp. 175-217, here p. 189 (including references to further relevant secondary literature). Origen formulates himself the guiding principle of an allegorical reading of the Bible in his treatise On First Principles, I, 3, ed. by P. Koetschau, in Werke, Vol. V: De prin-

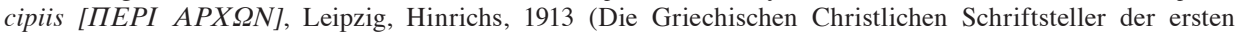
Jahrhunderte 22) (edition of the Latin translation, the Greek original being lost), p. 54,14-19; English translation by G. W. Butterworth, Origen, On First Principles, London, Society for Promoting Christian Knowledge, 1936 (reproduction: Gloucester, Mass., Peter Smith, 1973 [with a new Introduction by H. de Lubac]), p. 33: «Of course, these terms that we use, such as >always< or >has been<, or any similar ones that bear a temporal significance (vel semper vel >erat< vel si quod aliud tale temporalis significationis nomen adsciscimus), must be interpreted with reservations and not pressed; for they relate to time, but the matters of which we are now speaking, though described in temporal language for the purposes of discussion, in their essential nature transcend all idea of time (quoniam nominum quidem horum significationes temporales sunt, ea autem de quibus loquimur tractatu quidem sermonis temporaliter nominantur, natura autem sui omnem intelligentiam sensus temporalis exce$d u n t) »$. On Meister Eckhart's relation to Origen's works see Rubino, E., «[...] ein grôz meister: Eckhart e Origene», in L. Sturlese (ed.), Studi sulle fonti di Meister Eckhart, Vol. II, Fribourg (Switz.), Academic Press, 2012, pp. 141-165; Quero-Sánchez, A., «Origen of Alexandria and Meister Eckhart on the Imperfectibility of Being», in A. Brent and M. Vinzent (ed.), Papers presented at The Fifth British Patristic Conference, London 3-5 September 2014, Leuven, Peeters, 2016 (Studia patristica 74), pp. 117-145.

74 Meister Eckhart, Liber parabolarum Genesis, n. 1, LW, Vol. I/1, p. 447,2-6 (Recensio CT); LW, Vol. I/2, p. 333,2-5 (Recensio altera): Expeditis in prima editione quae dicenda videbantur quantum ad sensum apertiorem libri Genesis intentio nostra est in hac editione parabolarum [...] elicere quaedam «sub cortice litterae» parabolice contenta et tecta quantum ad sensum latentiorem. 
nitively prepared for publishing but it is rather to be seen in the context of Eckhart's academic lectures, particularly in relation with an introductory lecture for a course on some biblical book(s), probably -but surely not only- on the Book of Wisdom. It might originally have been either a collection of private notes used by Eckhart for such an introductory lecture or a reportatio made by some participant in the lecture. Recently, Loris Sturlese has written that this «Second Prologue to the Work of Commentaries» should be seen as being older than the aforementioned «First Prologue to the Work of Commentaries». ${ }^{75}$ And I think he is right. Eckhart says here very clearly that his interpretation will often be an allegorical one:

With regard to this work here, there are five aspects which should be [preliminary] noted. [...].

Thirdly, it should be noted that I frequently interpret these biblical verses in a sense which is different from the immediate meaning of the letter; they are relevant [not because of the literal sense but] because of the true and proper sense of the letter. ${ }^{76}$

This is a very strong reason, I think, to say that the first sentence of the Prologue to the Book of the Parables of Genesis, which I have already quoted above,$^{77}$ was not written -in contrast to what scholars have been hitherto thinking- by the author himself but by some anonymous editor after he had brought these two commentaries on Genesis together, which he, as Sturlese has shown, ${ }^{78}$ had previously found as separate works. This anonymous editor has read Eckhart's Prologue to the Book of the Parables of Genesis -in which Eckhart, as we have seen, actually emphasizes that he wants to interpret the texts allegorically- and he thought (so-to-speak in addition to this intention actually expressed by Eckhart himself) the following: «in contrast to what he (i.e. Eckhart) had done in the First Commentary on Genesis, that is, in the Expositio on Genesis». It is then not very difficult to detect how this anonymous editor proceeded by his edition of Eckhart's Prologue to the Book of the Parables of Genesis:

\section{Text published by Eckhart (reconstructed)}

My intention in this commentary of the Parables [...] is to work out some latent meanings which are allegorically contained «under the skin of the literal text».

\section{Text corrected by an anonymous editor (for publishing as a constituent part of the Three- Part Work) (I indicate his additions here in italics)}

After I have explained in the first commentary what, as it seemed to me, should be said concerning the manifest meaning of the Genesis, my intention in this commentary of the Parables [...] is to work out some latent meanings which are allegorically contained «under the skin of the literal text».

75 Cf. Sturlese, «Über die Entstehung und die Entwicklung», p. LII: «Wenn dem so ist, ist es kein Wunder, daß wir vor dem Sapientiakommentar einen Prologus in opus expositionum finden; denn der entsprechende Prolog ist gerade dort zu erwarten, wo Eckhart mit seinen expositiones begann -nämlich vor dem Liber Sapientiae. Kaum anzunehmen ist daher eine 〈spätere Entstehung〉 und eine 〈geringe Bedeutung〉 dieses Prologs im Vergleich zur Vorrede, die sich vor dem Genesiskommentar befindet, wie Konrad Weiß [cf. LW, Vol. I/1, pp. 124f.] schreibt».

76 Meister Eckhart, Prologus in Opus expositionum II, n. 1, LW, Vol. I/1, p. 183 (note 2), and n. 3, p. 184,6-8 (= LW, Vol. II, p. 321,2, and p. 321,9-11): In quo opere sunt quinque advertenda. // [...]. Tertio advertendum quod huiusmodi auctoritates frequenter adducuntur praeter intentionem primam litterae; secundum veritatem tamen et proprietatem litterae faciunt ad propositum.

77 See above, note 74.

78 Cf. Sturlese, «Über die Entstehung und die Entwicklung», p. XLVII. 
(Intentio nostra est in hac editione parabolarum [...] elicere quaedam «sub cortice litterae» parabolice contenta et tecta quantum ad sensum latentiorem).
(Expeditis in prima editione quae dicenda videbantur quantum ad sensum apertiorem libri Genesis intentio nostra est in hac editione parabolarum [...] elicere quaedam «sub cortice litterae» parabolice contenta et tecta quantum ad sensum latentiorem). ${ }^{79}$

And this is not an isolated case, because there are many other instances in which we can detect such an intrusion of an anonymous editor in Eckhart's original texts. This is especially the case, as both Konrad Weiß and Loris Sturlese have already detected, with regard to the «Recensio $\mathrm{CT} \gg{ }^{80}$ Let me quote a passage taken from the Expositio on Genesis as an example for this:

\title{
E (Erfurt) \\ L (Oxford) \\ CT Recensio (Kues and Trier)
}

And God said: «Let there be light». And God said: «Let there be light». And God said: «Let there be light» [...].

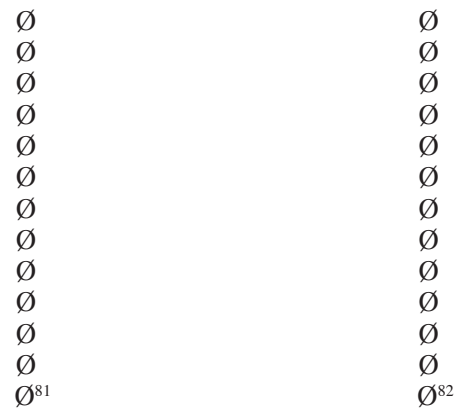

\begin{abstract}
«And God said». On the nature of God's «saying»-namely what he says and to whom among the divine and creatural beings he speaks, as well as how he speaks-, moreover: on how everything hears God's speaking and how it responds to him, you will find many nice comments on all these aspects in the second Commentary [on Genesis], namely in the Commentary on the Parables of Genesis. ${ }^{83}$
\end{abstract}

I do not think it is possible to conceive Eckhart writing about his own comments in the Book of the Parables of Genesis that they are «nice comments» (pulchra). This reference was surely not put there by Eckhart himself. But I think this is also the case with all the references to the «first» Commentary on Genesis, that is, to the Expositio on Genesis. We find in the «second» one, for example in $\S 8$, presenting an identical text in both recensions, $\mathrm{L}$ and $\mathrm{CT}$ :

«In the beginning God made heaven and earth».

This verse was interpreted in the first Commentary [on Genesis] in many different ways. With regard to the current intention [I have to say that] by these words is first expressed $[\ldots]^{84}$

79 Meister Eckhart, Liber parabolarum Genesis, n. 1, LW, Vol. I/1, p. 447,2-6 (Recensio CT); LW, Vol. I/2, p. 333,2-5 (Recensio altera).

80 Cf. K. Weiß, LW, Vol. I/1, pp. 107-110; Sturlese, «Über die Entstehung und die Entwicklung», pp. XXXIV-XLIV.

81 Meister Eckhart, Expositio libri Genesis, LW, Vol. I/1, p. 61,17 (Recensio E): «Dixit deus: fiat lux». [...].

82 Ibid., nn. 65f., LW, Vol. I/2, p. 113,8 (Recensio L): «Dixit deus: fiat lux». [...]

83 Ibid., LW, Vol. I/1, p. 230,1, and pp. 230,8-231,2 (Recensio CT): «Dixit deus: fiat lux». [...]. // «Dixitque deus». De natura [dicendi] dei, quid, quibus et qualiter loquatur in divinis et creaturis, rursus qualiter singula deum loquentem audiant et ipsi respondeant, invenies multa pulchra notabilia in secunda editione, Parabolarum scilicet in Genesim.

84 Id., Liber parabolarum Genesis, n. 8, LW, Vol. I/1, p. 479,2-4 (Recensio CT); LW, Vol. I/2, p. 348,2-5 (Recensio altera): «In principio creavit deus caelum et terram». // Verbum hoc in prima editione multipliciter 
The introductory formulation here («This verse was interpreted in the first Commentary [on Genesis] in many different ways. With regard to the current intention [I have to say that]»), was not written by Eckhart himself but by some anonymous editor after having brought together both commentaries on Genesis he had previously found as separate works. I am claiming therefore that there was an intervention or intrusion of a single anonymous editor maybe even of some various editors- in Eckhart's original texts not only with regard to the «Recensio CT», as both K. Weiß and L. Sturlese had already detected, but also in the «Recensio L» as we find it in the Oxonian manuscript (L), yet, as we have seen above, also in the «Recensio E» as it is contained in the Erfordian manuscript (E), that is, also in the earliest version we know of Eckhart's Three-Part Work.

\section{B.A. Distinction between a Published Work and its Previous Version as a Lecture Manuscript?}

As I have explained, the «classical» answer to the question why did Eckhart write two different Commentaries on Genesis is not right. Is there another possible explanation for this fact? Let us take a look at a work by Thomas of Erfurt, a contemporaneous author, Master of Arts at the School of St. Severus and at the Schottenkloster of St. Jacob in Erfurt, whose Commentary on Porphyry's Isagoge I am now editing at the Meister-Eckhart Research Center of the Max-Weber-Kolleg for Advanced Studies of the University of Erfurt (in collaboration with Markus Vinzent and Dietmar Mieth). ${ }^{85}$ Three manuscripts of this work are extant, preserved in Erfurt (E), Munich (M) and in Leipzig (L). The manuscript of Leipzig contains a reportatio of the school-lectures of Thomas of Erfurt, done by some anonymous student (Version $\beta$ ), whereas both the manuscripts of Munich (M) and the one of Erfurt (E) present a more elaborated version of the work, which was surely prepared for publication by the author himself (Version $\alpha){ }^{86}$ These two versions $(\alpha$ and $\beta$ ) are undoubtedly different versions of one and the same work, as we clearly notice from the following example:

exponitur. Quantum vero ad praesentem intentionem sub his verbis innuitur primo [...] (I am using here italics for indicating the additions of the anonymous editor to the original text by Eckhart).

85 See Vinzent,, M., «Personal Pronouns: Thomas of Erfurt and Meister Eckhart in Erfurt and Paris», in Id., and Chr. Wojtulewicz (eds.), Thomas von Erfurt und Meister Eckhart, Leiden, Peeters, 2016 (Meister Eckhart: Texts and Studies 7) (in press); Quero-Sánchez, A., «Heideggers Missverständnis der averroistischen Abbildtheorie der Sprache des Thomas von Erfurt in seiner Freiburger Habilitationsschrift (Die Kategorien-und Bedeutungslehre des Duns Scotus)», ibid.. See also Mieth, D., Meister Eckhart, Munich, Beck, 2013, pp. 90-98; Mantas España, P., «Introducción al lebendiger Geist en el Duns Scotus de Martin Heidegger», Revista española de filosofía medieval, 18 (2011), pp. 151-163.

86 On both a description of all these manuscripts and a discussion of the relationship existing between them see Quero-Sánchez, «Heideggers Missverständnis» (2016), Appendix. 


\section{M/E (Version $\alpha)$}

And these [i.e. the sciences] can be further divided up. There are mechanical sciences, whose aim consists in satisfying the needs of body, e.g. agriculture, spinning, navigation, hunting and similar activities. They are called «mechanical» in the sense of the verb moechari, which means «to commit adultery». A «mechanical» science is therefore an adulterous and vile science. For in the same way as the body and [merely] corporeal things are viler than those referring to the soul, so also mechanical sciences are viler than the liberal ones.

There are also «liberal» sciences, which are so called because they «liberate» man from earthly fears, elevating him to the love of heavenly things. ${ }^{87}$

\section{L (Version $\beta$ ) (reconstructed from the extant reportatio)}

Leaving out of our consideration these «sciences» [i.e. the so-called «magical» sciences] -because they are entirely useless-, we can further divide the human sciences up in mechanical and liberal sciences.

There are mechanical sciences, which have been invented in order to satisfy the needs of body as well as to overcome the lacks of body, e.g. spinning, navigation, carpentry, shoemaking, etc. They are called so [i.e. «mechanical»] in the sense of the verb moechari, which means «to commit adultery». For in the same way as an adulterous woman is viler than a woman who loves his husband in a right manner, so also mechanical sciences are viler than the liberal ones.

These are called «liberal sciences» in the sense of the verb «to liberate»: because they «liberate» the soul from earthly fears, elevating it to the love of heavenly things. Or [to give another explanation for this denomination]: They are called so in the sense of the [Latin] word liberi: because only the children of free and noble men used to cultivate these liberal sciences. ${ }^{88}$

Do we have to interpret the relationship between Eckhart's Expositio on Genesis and his Book of the Parables of Genesis in a similar way? Is Eckhart's Book of the Parables of Genesis the published version of his previous academic lectures as we find them in the Expositio on Genesis? This is clearly not the case. Let me just take Eckhart's interpretation of Gn 1,1 as example:

87 Thomas of Erfurt, Commentum in Isagogas Porphirii (Version $\alpha$ ), 〈Introduction〉, ed. by A. Quero-Sánchez, «Heideggers Missverständnis» (2016), Appendix: Et istae dividuntur, quia quaedam est mechanica, quae ordinatur ad supplendum defectus ex parte corporis, cuiusmodi sunt agricultura, lanificium, navigatio, venatio et caetera huiusmodi. Et dicitur a «moechor», «moecharis», quod est «adultero», «adulteras»; inde «mechanica» est idem quod adultera et vilis, quia sicut corpus et ea quae sunt corporis respectu animae sunt vilia, sic scientia mechanica est vilis respectu scientiae liberalis. // Quaedam autem est «liberalis», quae sic dicitur, quia hominem a curis terrenorum «liberat» et in amorem caelestium erigit.

88 Ibid. (Version $\beta$ ), ed. by A. Quero-Sánchez, ibid.: Ista obmissa-quia nihil est, sed magis inutilis-ulterius scientia humana dividitur in scientiam humanam mechanicam et in scientiam humanam liberalem. // Est autem scientia humana mechanica adinventa ad supplementa et necessaria corporis et ad tollendum defectum corporis, ut est lanificium, navigatio, fabrilis, sutoria, etc. Et dicitur a «moechor», «moecharis», quod est «adultero», «adulteras», quia sicut adultera vilis est respectu debiti amoris viri coniugalis, sic etiam artes mechanicae viles sunt respectu artium liberalium. // Dicuntur autem «artes liberales» a «libero», «liberas», quia liberant animam a curis terrenorum et erigunt eam in amorem caelestium. Vel dicuntur a «liberis», quia solum filii liberorum et nobilium ad artes liberales applicari solebant. 


\section{Expositio on Genesis}

«In the beginning God made heaven and earth».

Four previous remarks should be explained concerning this verse. First: We have to explain what is this beginning [or «principle»] (principium) in which God is said to have made heaven and earth. Second: How can it be that it is said: «He made in the beginning heaven», although we read in the Psalm [101,26] as well as in the first Epistle to the Hebrews $[1,10]$ : «You have set up earth at the beginning, o Lord»; and it is also said in Ecclesiasticus $[18,1]$ : «He, who lives in eternity, made everything simultaneously». Third: That what is One can make by nature just one thing, therefore: how can it be that God, who is pure Oneness, always being in one and the same manner, produced or «made at the beginning heaven and earth», which are so different from each other; and how can it be that «he made everything simultaneously». Fourth: Based on what it has been said, we conclude that any thing which is less perfect than God [is not by itself but] receives its being from outside and from another thing; nonetheless, this thing has its received being in its inner, it is its own being, by which the thing first comes to [properly] exist. ${ }^{89}$
Book of the Parables of Genesis

«In the beginning God made heaven and earth».

This verse was interpreted in the first Commentary [on Genesis] in many different ways. With regard to the current intention [I have to say that] by these words is first expressed the eternal production or emanation of both the Son and the Holy Spirit from the Father. [By these words] are also expressed the temporal general production or creation of the whole universe from the one God as well as many [further] aspects concerning the properties of both creator and creatures. ${ }^{90}$

After having introduced these aspects Eckhart actually discusses them in the following passages, interpreting the first verse of Genesis. We clearly see therefore that Eckhart's Expositio on Genesis and his Book of the Parables of Genesis are not two different versions of one and the same work, but two different works throughout. It is possible, of course, to find some -few- passages being similar in both Commentaries, but this is not the normal case. So the question still remains: Why did Meister Eckhart write two different Commentaries on Genesis?

89 Meister Eckhart, Expositio libri Genesis, n. 2, LW, Vol. I/1, p. 186,2-12 (Recensio CT); LW, Vol. I/2, p. 61,3-12 (Recensio L): «In principio creavit deus caelum et terram». // Circa praemissam auctoritatem quattuor sunt praenotanda. Primo, quod sit hoc principium in quo deus dicitur creasse caelum et terram. Secundo, quomodo dicitur creasse in principio caelum, cum in Psalmo et Hebr. 1 dicatur: «initio tu, domine, terram fundasti», et Eccli. dicatur: «qui vivit in aeternum, creavit omnia simul». Tertio, cum unum semper natura [corrected from natum] sit unum facere, quomodo deus, unus simplex, semper eodem modo se habens, produxerit sive creaverit in principio caelum et terram, tam diversa, et omnia simul. Quarto ex hoc concluditur quod omnia citra deum habent esse aliunde quidem et ab alio, et tamen nihilominus nihil tam intimum, nihil tam primum et proprium quam ipsum esse.

90 Id., Liber parabolarum Genesis, n. 8, LW, Vol. I/1, p. 479,2-7 (Recensio CT); LW, Vol. I/2, p. 348,2-8 (Recensio altera): "In principio creavit deus caelum et terram». // Verbum hoc in prima editione multipliciter exponitur. Quantum vero ad praesentem intentionem sub his verbis innuitur primo productio sive emanatio filii et spiritus sancti a patre aeternaliter, item productio sive creatio generalis totius universi ab uno deo temporaliter, et plura quantum ad proprietates tam creatoris quam creaturarum. 


\section{A. Distinction between a Published Book and a Lecture Manuscript being not a Previous Version of the Published Book}

In contrast to what is the case with Eckhart's Book of the Parables of Genesis, his Expositio on Genesis is not a book published by Eckhart himself. This becomes obvious by looking at the numerous passages contained in the Expositio, in which some ideas are just referred to but not explained at all. We have to see Eckhart's Expositio on Genesis in relation to his academic lectures, be it at the University of Paris, be it at the Dominican Studium generale in Cologne, be it at the Dominican Convent in Erfurt or elsewhere. That is surely the reason why we find some «bibliographical remarks» at the very beginning of the work, in Eckhart's interpretation of Gn 1,1 (in $\S 1$, just before $\S 2$ which I have just quoted), ${ }^{91}$ which are characteristic -even today-for academical lectures:

Augustine discusses in detail this beginning of Genesis, especially in his Literal Commentary on Genesis, his Commentary on Genesis against the Manichaeans as well as in the last three books of his Confessions. See also Ambrose [of Milan] and Basil [of Caesarea]: their works on the creation of the world. See also Maimonides, especially the second book [of his Guide for the Perplexed], chapter 31. See also Thomas [Aquinas], in the first part [of his Summa Theologiae], questions 44, 45, 46 and 47, as well as in the later questions 65 to 74 of the same first part [of the Summa Theologiae]. ${ }^{92}$

The text of the Expositio on Genesis is certainly, as I said, unfinished, it presents nonetheless a good quality, which shows that it is not based on a reportatio made by some student in the course of Eckhart's lectures, but on the lecture-manuscript used by Eckhart himself. Let me quote another passage, in which this becomes especially clear. Eckhart asks first: «Why does Moses not say anything about time, namely about any <day>, when he is speaking about the creation of heaven and earth?». ${ }^{93}$ And he then answers this question himself: «You should say [to this] that creation comes about before, beyond and without time». ${ }^{94}$ Eckhart uses here a formulation (dic quod [...], that is, «you should say [to this] that [...]») that we also find in his Latin Sermons, which constitute, as is well-known, not a published work but an unfinished one, based on a manuscript Eckhart used in preaching or at least in preparing his preaching. We read in the Latin Sermon XXII for example: «In relation to this, you should quote [the following sentence] from Augustine's Commentary on John: «the benefit of a right life is that man live forever . For eternal life is because of the grace of God». ${ }^{95}$

As it is the case with Eckhart's Latin Sermons as they are contained in the manuscript of Kues (C), we have to conclude here, with regard to his Expositio on Genesis, that the work was

91 See above, p. 283.

92 Meister Eckhart, Expositio libri Genesis, n. 1, LW, Vol. I/1, p. 185,2-6 (Recensio CT); LW, Vol. I/2, p. 59,12-16 (Recensio L): Exordium hoc scripturae Genesis tractat Augustinus diffuse, specialiter «Super Genesim ad litteram» et «Super Genesim contra Manichaeos» et in tribus ultimis libris «Confessionum». Item Ambrosius et Basilius in suis «Hexaemeron». Item Rabbi Moyses l. II c. 31 specialiter. Item Thomas p. I q. 44, 45, 46 et 47, item post ibidem q. 65 usque ad 74 inclusive.

93 Ibid., n. 73 [!], LW, Vol. I/1, p. 235,6f. (Recensio CT); n. 66 [!], LW, Vol. I/2, p. 113,15f. (Recensio L): Quid est quod Moyses loquens de creatione caeli et terrae tacet de temporibus, scilicet de diebus?

94 Ibid., n. 73 [!], LW, Vol. I/1, p. 235,8f. (Recensio CT); n. 66 [!], LW, Vol. I/2, p. 113,16f. (Recensio L): Dic quod creatio utique ante tempus, supra tempus et sine tempore est.

95 Id., Latin Sermon XVII, n. 171, LW, Vol. IV, ed. by E. Benz, Br. Decker and J. Koch, Stuttgart, Kohlhammer, 1937-1956 (repr. 1987), p. 163,9-11: Tu dic [...] cum Augustino super Ioh.: «ad hoc debet unicuique prodesse bene vivere, ut detur illi semper vivere», quia 〈gratia dei vita aeterna〉. On this Sermon see Quero-Sánchez, «Sermo XVII» (2009). 
-in contrast to what is the case with the Book of the Parables of Genesis-not intended by Eckhart to be published, at least not in the form in which the work is extant. Eckhart's Expositio on Genesis was originally a manuscript of the author to be used in teaching. But this private manuscript came into circulation among students and scholars, surely already during Eckhart's lifetime as well as with his consent. ${ }^{96}$ It was not a «published» but became nevertheless a «public» work.

\section{THE BOOK OF THE PARABLES OF GENESIS: MEISTER ECKHART'S CRITIQUE OF NATURALISM}

Eckhart's Book of the Parables of Genesis is, as we have seen, a published (by Eckhart himself) work. Now, since it does not represent a new, further developed and prepared version for publishing of the Expositio on Genesis, we should admit that the work was not -at least not primarily- addressed to students of theology, but to someone else. This would explain why there are two different Commentaries on Genesis by Meister Eckhart. The question now is therefore the following: To whom is Eckhart's Book of the Parables of Genesis addressed?

\section{A. Beyond Facticity: Eckhart's Interpretation of Genesis 1,1 («In the beginning God made heaven and earth»)}

In order to answer this question, let us first take a look at Eckhart's interpretation of Gn 1,1 («In the beginning God made heaven and earth») in the Book of the Parables of Genesis. I start my analysis by quoting the immediate continuation of $\S 8$, which I have quoted above: ${ }^{97}$

«In the beginning God made heaven and earth».

[...].

We have to acknowledge that in any natural action or production, the principle which brings about something outside of the producer, by proceeding from something which is not [e.g. which is not white] to something which is [e.g. which is white], is to be defined as a «cause». [On the other hand], a [by such a natural process] produced thing is to be called and defined as a «fact» (factum) and as a «fact being outside [of its cause or producer]» (factum extra) [i.e. «something done», a mere «product» (factum), or a (mere) «product just having been put there by an external cause» (extra factum)]. The first sentence is in accordance with that what Aristotle says: «a cause is something to which» or from which «follows something else»; the second is in accordance with the [meaning of the] term «effect» (effectus). For «effect» (ef-fectus) sounds like «something done outside [of the cause or producer]» [i.e. a (mere) «product just having been put there by an external cause»] (extra factus) or as «something done outside of its maker» (factum extra facientem). Such a [mere] product is something «created» or a [mere] «creature», both because it has been produced outside of its producer and because it has been produced by proceeding from something which is not to something which is, for

96 This must have been the case, because some passages of Eckhart's Expositio on Genesis were examined in the course of his inquisition trial in Cologne, with Eckhart himself trying to justify them in his Response, which means that he acknowledged this work as his own. See, for example, Meister Eckhart, Responsio ad articulos sibi impositos de scriptis et dicits suis, n. 120 (Processus Coloniensis I), LW, Vol. V, ed. by L. Sturlese, p. 290,6-11 (Eckhart's Response to Processus Coloniensis I, n. 43, ibid., pp. 312,25-313,3 (= Expositio libri Genesis, n. 7, LW, Vol. I/2, p. 65,8-23).

97 See above, p. 283. 
example [by the natural conception of a horse]: from something which was not [yet] a horse to something which is [now] a horse, or [to put another example: when we paint a wall which was red in white]: «from something which was not white to something which is [now] white».

From what has been said about natural production it becomes clear that in the case of divine [i.e. not merely natural] beings, since the production or emanation here [e.g. the emanation of the Son from the Father] does not bring the produced «thing» to be outside of the producer, nor does it come about by proceeding from something which is not (or [even] from nothing), nor -thirdly- by proceeding to a certain [or determined] manner of being (esse hoc), therefore the created «thing» is not a [mere] «fact» [i.e. not «something having merely been done by an external cause»] (factum) nor «something having [merely] been created» (creatum) nor a [mere] «effect». In this case, the producer should not be called nor defined as [mere] «creator» or [mere] «cause», and the «product» is not outside of the producer nor is it something different from the producer himself, but it constitutes a unity with the producer. [...]. And that is what the verse means: «In the beginning God made heaven and earth». Creation is a production of things from nothing. Heaven and earth are something which [merely] is in a certain, determined manner [i.e. in this or that determined manner] (ens hoc et hoc); the Son, however, and the Holy Spirit are, as it has been said before, not [merely] in a certain, determined manner [i.e. not merely in this or that determined manner] (non sunt hoc et hoc), but they «are» in the absolute meaning of the word (esse simpliciter), they are in a complete and full manner, and they proceed not from nothing [but from God the Father]..$^{8}$

My translation here is, of course, a certain interpretation of the passage: What things (in the proper sense) «are», that is, what things «really» are, is not merely defined or just determined by their natural way of being (esse hoc), but they only are «really» by realising their absolute or divine being, which is, Eckhart says, not just a certain, particular or determined way of being, but rather being in an absolute manner (esse simpliciter seu absolute). The philosophical position Eckhart is criticising in this passage defines reality as something merely «being there», as a whole consisting of «facts» (facta) or «products» (facta) being there as determined by some external causes (effecta). According to such a metaphysical position, we would have to consider reality as a whole of effects: as things presenting a certain way of being determined by their natural form: things which are merely there, re-acting in a characteristic manner defined by their form to different causes influencing -or just determiningthem. In his Book of the Parables of Genesis, Eckhart is not just interpreting Genesis but

98 Meister Eckhart, Liber parabolarum Genesis, n. 9, LW, Vol. I/1, pp. 479,8-480,6 (Recensio CT); LW, Vol. I/2, pp. 348,9-349,5 (Recensio altera): «In principio creavit deus caelum et terram». [...]. Sciendum ergo quod in naturalibus in omni actione sive productione, quae est ad extra producentem et quae est ex non ente aliquo et ad ens aliquod, principium talis productionis habet rationem causae et ipsum quod producitur habet nomen et rationem facti et extra facti. Primum patet ex philosopho qui ait: "causa est, ad quam» sive ex qua «sequitur aliud». Secundum patet ex ipso nomine. Effectus enim sonat extra factus sive factum extra facientem. Ex quo patet consequenter quod tale productum habet rationem creati sive creaturae, tum quia producitur extra producentem, tum quia producitur ex non ente aliquo ad ens aliquod, puta equus ex non equo, «album ex non albo». // Ex hoc autem primo, quod dictum est in naturalibus productionibus, patet quod, in divinis productio sive emanatio omnis cum non sit ad extra producentem nec sit ex non ente sive ex nihilo nec etiam tertio sit ad esse hoc, productum non habet rationem facti nec creati nec effectus et producens non habet nomen aut rationem creatoris nec causae et productum non est extra producentem nec aliud, sed unum cum producente. [...]. Hoc est ergo quod hic dicitur: «creavit deus caelum et terram». Creatio enim est productio ex nihilo, caelum et terra sunt ens hoc et hoc, filius autem et spiritus sanctus, ut dictum est, non sunt hoc et hoc, sed esse simpliciter, totum et plenum esse, nec sunt ex nihilo. 
primarily critisicing -by an interpretation of Genesis- such a radical naturalistic, almost positivistic position. «Radical Naturalism» means here just a position according to which we have to refer our judgements on morals and metaphysics to things as they naturally are, to things as we can know them starting from our sense-experience. We have, so it seems, to accord our life to the facts (facta) ${ }^{99}$ Meister Eckhart's Book of the Parables of Genesis is surely to be seen in this context: as a published treatise (by Eckhart himself in this form) arguing for a non-naturalistic position, trying to show that you cannot use Genesis -particularly not Gn 1:31 («God saw every thing that he had made, and, behold, it was very good»)- to defend Naturalism as the Christian position..$^{100}$ You can -maybe you even «have to»- interpret Genesis in a nonnaturalistic way. Let me show such an intention by analysing a further passage in the Book of the Parables of Genesis, namely Eckhart's interpretation of the third chapter of Genesis, beginning with the verse: «Now, the serpent was more crafty than any other beast of the field that the Lord God had made» $(\mathrm{Gn} 3,1) .{ }^{101}$

99 «Naturalism» is of course a very problematic concept which I would not like to discuss here but only in the context of a detailed interpretation of Eckhart's Book of the Parables of Genesis.

100 See on this Quero-Sánchez, A. «Non-Situated Being: On the Reality of Nothing», in J. Vinzent and Chr. Wojtulewicz (eds.), Performing Bodies: Time and Space in Meister Eckhart and Taery Kim, Leuven, Peeters, 2016, 143-166 («Meister Eckhart's Idealism as Christian Realism: Not Succumbing to the Temptation»).

101 I am grateful to John M. Connolly for drawing my attention to these passages by Eckhart in a Guest Lecture at Max Weber Centre for Advanced Cultural and Social Studies on the 23 ${ }^{\text {rd }}$ June 2015: «Tatort Garten Eden. Meister Eckhart über die Ursünde». According to Connolly, Eckhart's position is to be seen as a sort of «naturalism of second, elevated or true nature»; cf. Connolly, J. M., Living without Why. Meister Eckhart's Critique of the Medieval Concept of Will, Oxford, University Press, 2014, pp. 209f.: «So Eckhart's philosophical pedigree is flawless. Yet, although Plato and Aristotle (sometimes with at least a passing reference to Augustine, Aquinas, and even William of Ockham) are taught today in virtually every Western-oriented philosophy department, in most of them Eckhart's thoroughly Platonic/Aristotelian works must seem outlandish. Why is this? With some few exceptions (notably at Catholic Universities) Western philosophy departments today are dominated by a scientific (and often scientistic) outlook inherited from Cartesianism and, especially, British empiricism. [...]. Talk of God is today often relegated to the religious studies department, while the philosophy of psychology takes its cues largely from neuroscience and computationalism, and the general outlook is often dubbed «naturalistic>. And yet some essential aspects of Eckhart's project are not altogether beyond the range of interests of philosophers within this self-styled naturalistic tradition. One sign of this is the mainstream revival of virtue ethics in recent decades, which of course has its roots in Aristotle and his successors. The idea that virtuous behavior is the core of living well lies close to the heart of Eckhart's views». See also ibid., pp. 191f.: «Indeed, his [i.e. Eckhart's] idea that the just person qua just acts justly for its own sake, and not for some goal distinct from it, is Aristotelian though and through. So another way to express the idea of 〈living without why) would be to say: 〈live virtuously! i.e., 〈virtuously-2〉, that is, be just, good, wise, etc., as God is, without thought of reward, without the spiritual merchant's mentality, for that is your true nature» (my emphasis). See also McDowell, J., «Two Sorts of Naturalism», in id., Mind, Value, and Reality, London/Cambridge, Mass., Harvard University Press, 1998, 167-197, here pp. 168f.: «The reading [of Aristotle I am rejecting] makes it difficult to place an attractive thesis of Aristotle's, to the effect that virtuous actions are -presumably rightly- seen by a virtuous person as worth performing for their own sake. [...]. // Similarly, consider the thesis that a virtuous person acts 〈for the sake of the noble). A virtuous action's appeal to reason -which a virtuous person gets right- consists in the action's being noble. This goes well with the suggestion that virtuous action appeals to reason in its own right, not as needed to secure some good whose status as such can be recognized independently of whether virtue's demands on reason are genuine»; ibid., pp. 184f.: «Virtue of character embodies the relevant proper state of practical logos, what Aritotle calls 〈phronêsis $\rangle$ - 〈practical wisdom〉 [...]. [...]. The practical intellect's coming to be as it ought to be is the acquisition of a second nature, involving the moulding of motivational and evaluative propensities: a process that takes place in nature. The practical intellect does not dictate to one's formed character - one's nature as it has become- from outside. One's formed practical intellect -which is operative in one's character-revealing behaviour-just is an aspect of one's nature as it has become». 


\section{B. «Unless the Lord Watches over the City, the Watchman Stays awake in Vain» (Psalm 127,1): Eckhart's «Naturalism of Restored Nature»}

How does Eckhart interpret the third chapter of Genesis, which contains the narration of the original sin of man and his following expulsion from paradise? «Serpent», «woman» and «man» are here interpreted by Eckhart, of course, in an allegorical way (parabolice). The «Serpent» means, he says, the «senses», which tell us how things factually are; the «woman» represents «inferior reason», which has as such, Eckhart says, an inclination to hear or yet to obey the senses telling her how things (allegedly) «are» or what is (allegedly) «right»; the «man», finally, represents in this story «superior reason», which listens to what God says and not to what inferior reason, which is ultimately dependent upon the senses (that is, upon factual things and causal relations), determine to be (allegedly) right:

[...] with these words -«serpent», «woman» and «man»- is expressed the way in which the «serpent», that is, the senses, actually and literally speak with the «woman», that is with inferior reason, and how this inferior reason speaks with her superior, as well as how this highest sphere [that is superior reason] speaks with God. ${ }^{102}$

However, it is important to notice that we do not have to consider such an allegorical interpretation by Eckhart as expressing any contempt of woman, since Eckhart, as is wellknown, is an author with a very positive consideration of the role women should play in society. ${ }^{103}$ His interpretation of the third chapter of Genesis is not to be seen as a thesis in genderstudies but just as a metaphysical one: as a reaction to a radical «naturalistic», almost «positivistic» interpretation of Genesis.

The relationship between these four agents, that is, between senses, inferior reason, God and superior reason, is, Eckhart says, not the same in the state of man «before (original) sin» (ante peccatum), in the state of man «under sin» (sub peccato), which is the actual or normal state of nature, and in the state of man «after sin» (post peccatum), which latter is not the normal or actual state of nature but the state of nature after having been «restored» to its original right state by the action of divine grace. ${ }^{104}$ The «right» constitution of man was, of course, the one he had in the state «before (original) sin», in which he was what he «really» or «in the proper sense» is:

«The rightness of man» «was»-and is- when the senses conform and subordinate themselves to inferior reason, when inferior reason obeys and subordinates to superior reason, and superior reason conforms and adheres to God, according to what is said in Ecclesiasticus, chapter 7 [29]: «God made man upright». This was -and is- the state constituting the nature [of man] «before (original) sin», that is «the state of innocence». ${ }^{105}$

102 Ibid., n. 137, LW, Vol. I/1, p. 603,10-15 (Recensio CT); LW, Vol. I/2, p. 400,5-9 (Recensio altera): [...] in his verbis: serpens, mulier et vir exprimitur [...] quomodo serpens, sensitivum scilicet, verissime et ad litteram loquitur mulieri, inferiori scilicet rationalis, et quomodo illud inferius rationale loquitur suo superiori, et hoc supremum loquitur deo.

103 See on this especially Mieth, Meister Eckhart (2013), p. 97; Mulder-Bakker, A., «Fromme Frauen in Straßburg und Meister Eckhart: Gertrud von Ortenberg and Heilke von Staufenberg», in Fr. Löser and D. Mieth (eds.), Religiöse Individualisierung (2014), pp. 55-74, here pp. 71-74.

104 Cf. Meister Eckhart, Liber parabolarum Genesis, n. 137, LW, Vol. I/1, pp. 603,10-604,1 (Recensio CT); LW, Vol. I/2, p. 400,5-11 (Recensio altera): in his verbis: serpens, mulier et vir exprimitur [...] quomodo ista tria respiciunt triplicem statum hominis, scilicet ante peccatum, sub peccato et post peccatum.

105 Ibid., n. 143, LW, Vol. I/2, p. 612,1-7 (Recensio CT); LW, Vol. I/2, p. 403,11-16 (Recensio altera): «Haec fuit» et est «rectitudo hominis», quando sensitivum oboedit rationi inferiori et ad ipsam respicit et ordinatur et 
The crucial expressions in this passage are surely rectitudo, that is «rightness», and rectum, i.e. «right». At the beginning, in the state «before (original) sin», man was what he in the proper sense «is», he was, so to speak, not outside but inside his concept: he was in an essential way or essentially, that is, in accordance with his own or proper essence. But even this «rightness» was destroyed by original sin, so that it is now not any more possible to define what man properly or really is by starting from a knowledge of what individuals actually, usually, generally or in the normal case are. That is the reason why you cannot use Genesis in order to support naturalistic or yet positivistic metaphysics. Eckhart expresses his position by quoting Psalm 127,1: «Unless the LORD watches over the city, the watchman stays awake in vain». ${ }^{106}$ Sense-experience, which certainly tells us how things actually, usually, generally or in the normal case -that is even: «naturally»- are, cannot instruct us about how things really, in the proper sense or essentially are, unless the factual existing things had first become «right», that is, unless they had become how they should be or how they (in the proper sense, essentially or really) are. However, things are not «right» by themselves but only, Eckhart says, because of God or by grace, which restores the original state of things «before (original) sin» (ante peccatum), as they were when they really or essentially were. This is again the crucial thesis of Eckhart that I have quoted above: «Right, the more we ourselves are, the less are we ourselves (= the less are we [in a proper sense])» (Jâ, ie mer wir eigen sin, ie minner eigen). ${ }^{107}$

What is important to emphasize is that by his referring to grace as the crucial element in metaphysics, Eckhart is not standing up for an irrationalistic account, but, on the contrary, he is proposing reason as the fundamental element defining what things and especially man really- are; he is defending thereby the primacy of the concept over (merely) given facts. Eckhart is, of course, not defending reason as a power depending upon given facts. For facts can be -and they actually often are- wrong. So, for example, you cannot define reason by describing how individuals actually, usually, generally or in the normal case «argue», but you have to do it without any reference to experience at all. And afterwards, you will be able to raise the question whether a certain man being factually there -a certain individual- is a rational one, that is, whether he «factually» is what he «really», «in the proper sense» or «essentially» is. For man should be rational in order to be what he really or essentially is (animal rationale). And in virtue of his being-rational, man becomes what he was «before (original) $\sin »$, which constitutes also the state of man not «under sin» (sub peccato) -as a mere thing determined by the factual given form or nature of man- but «after sin» (post peccatum), namely after God's grace having restored the original state of man «before (original) sin» (ante peccatum):

The state of man after sin comes about when by grace he is redirected to God. And then, the more the highest element of the soul adheres to God, the more the inferior element, also the senses, obeys it [i.e. this highest element]. In this state it is granted to individuals perfected by grace that their senses obey their inferior reason, while this obeys superior reason. ${ }^{108}$

illa subhaeret et adhaeret rationi superiori et ipsa deo, secundum illud: «deus fecit hominem rectum», Eccl. 7. [...]. Iste fuit et est status naturae institutae ante peccatum, «status innocentiae».

106 Ibid., n. 144, LW, Vol. I/2, p. 613,15 (Recensio CT); LW, Vol. I/2, p. 403,25 (Recensio altera): «nisi dominus custodierit civitatem, frustra vigilat, qui custodit eam».

107 Id., Talks of Instruction, DW, Vol. V, p. 230,8. See above, p. 271.

108 Id., Liber parabolarum Genesis, n. 145, LW, Vol. I/2, p. 613,6-10 (Recensio CT); LW, Vol. I/2, p. 403,2630 (Recensio altera): Status autem hominis post peccatum est, quando per gratiam reordinatur homo in deum. Tunc enim, quo magis adhaeret supremum animae ipsi deo, tanto magis sibi oboedit inferius se, etiam sensiti- 
This is Eckhart's -allegedly irrational- «mysticism»: nothing but a critique of positivism and radical naturalism from the point of view of absolute reason.

Fecha de recepción: día 28 de febrero de 2016

Fecha de aceptación: día 9 de septiembre de 2016

vum. In hoc statu ex abundantia et perfectione gratiae conceditur viris perfectis, ut sensitivum sic oboediat rationi inferiori et illa rationi superiori. 